\title{
Analysis of Correlational Behavior of Solvent and Insolvent Firms Based on Accounting Ratios*
}

\author{
Mario Situm \\ University of Applied Sciences, Kufstein, Austria
}

\begin{abstract}
The concept of crisis evolution is still not fully understood, despite over 40 years of research into investigations in the field of crisis and insolvency prediction. This is due to the fact that the financial situation of a firm changes within an unobservable life cycle continuum, comprising different economic states which are not in fact properly defined. The aim of this study was to contribute towards a better understanding of the differences between solvent and insolvent firms for the periods of one and two years prior to insolvency respectively. Through the application of correlation and factor analysis, an attempt was made to detect behavioral patterns in accounting ratios, which can in turn explain differences and similarities between the two groups of firms. The results of this study show that although accounting ratios from two consecutive years had low correlations for both groups of firms, they were much higher for insolvent firms. This provides evidence that the economic and financial situation of insolvent firms is much more dependent on its history when compared to solvent firms. Moreover, there is evidence to suggest that the change of the economic and financial situation of insolvent firms within the life cycle continuum tends to follow a predetermined path, in contrast to the more random nature of a solvent firm's behavior. Additionally, the results showed that the factor loadings for solvent and insolvent firms differ for both observation periods, indicating that there are different underlying factors affecting the final outcomes for the two groups of firms. This is mainly attributable to disturbances in the scaling factors of total assets for both observation periods, as well as the disappearing size factor for the pre-distress year for insolvent firms, based on factor analysis.
\end{abstract}

Keywords: insolvency prediction, corporate crises, crisis indicators, correlation analysis, factor analysis

\section{Introduction}

The attempts to understand both the evolution of corporate crises and finally the event of insolvency are manifold within business research. No common theory currently exists for corporate crises or insolvencies which can be connected to generally accepted and recognized financial theories (Yim \& Mitchell, 2007; Agarwal \& Taffler, 2007). It is therefore of scientific interest that more research in the field of crisis and insolvency prediction be conducted, in order to understand how crises develop within enterprises and whether there are certain patterns which could be identified and transformed into a theoretical framework.

This already indicates the way that research in this field is conducted. Above all, there is no theoretical common ground to use as a starting base. Instead, empirical data containing financial and non-financial ratios

\footnotetext{
* Acknowledgement: Mario Situm would like to thank the "Fonds zur Förderung der wissenschaftlichen Forschung und des wissenschaftlichen Nachwuchses in Tirol” for funding support.

Mario Situm, professor for Corporate Restructuring, Institute for Corporate Restructuring, University of Applied Sciences. Email: Mario.Situm@fh-kufstein.ac.at.
} 
are collected for different samples and different time periods in order to compute statistical measurements. The results are then used to develop early warning models which are capable of classifying a firm into a defined category. Therefore, these approaches deliver a pattern recognition (Coats \& Fant, 1993; Butera \& Faff, 2006; Agarwal \& Taffler, 2007), which can be used to investigate the different behavioral and evolutionary paths that firms within different economic states are taking. Every step and additional empirical evidence is helpful for a better understanding and could, in future, provide the link to the missing theoretical framework.

No forecasting model has yet been developed from this work. Instead, correlation and factor analysis was applied to investigate the behavior of solvent and insolvent firms in Austria for the periods of one and two years respectively prior to insolvency. Generally, it seems that the two types of firms must display different patterns, as their final outcome (solvency or insolvency) denotes totally different economic states. Financial distress and its progression towards insolvency can be seen as an anomaly of the "normal" economic condition of a firm and the challenge is therefore to detect this "anomaly" as early as possible. Both methods mentioned above can provide interesting insights into how correlations are changing over time and whether accounting variables are linked to the same factors. Specifically, the aim was to recognize for which type of firm the actual economic and financial condition described by accounting ratios is more dependent on its past performance and what this aspect means for the early prediction of corporate bankruptcies.

It is interesting to note that such an attempt had not been applied in prior research, based on a review of 250 papers related to the topic of crisis and insolvency prediction. In these papers, a small minority of researchers applied correlation and factor analysis (or principal component analysis) in order to detect common underlying factors for accounting ratios. It must be noted, however, that in these papers both types of firms (solvent and insolvent) were not separated, whereas in this study, such a separation was made (Laurent, 1979; Chen \& Shimerda, 1981; Pohlman \& Hollinger, 1981; Min \& Lee, 2008; Chen, Liao, \& Lu, 2011; Li \& Sun, 2011; Lin, Yeh, \& Lee, 2013). Therefore, the results of this study provide new evidence for research which will give a better understanding of the evolution of corporate crises and how solvent and insolvent firms differ in their behavior concerning the change within the life cycle continuum, based on accounting ratios.

This paper is organized as follows: Firstly, a literature review is provided, analyzing prior research into the methods used to develop credit assessment models, an overview of studies which have investigated certain economic and financial states of companies within the two dichotomous situations of bankruptcy and non-bankruptcy, as well as the justification of accounting ratios for prediction purposes; secondly, the data base for the research, the research hypothesis, and the research questions are presented; thirdly, descriptive statistics with testing for normality of data were applied; fourthly, tests for differences were computed in order to recognize the best discriminating variables for the two years of the observation period; fifthly, correlation analysis was applied for both groups of firms, supplemented by factor analysis; and finally, the main conclusions are summarized and presented, and recommendations are provided.

\section{Literature Review}

\section{Methods for the Construction of Credit Assessment Models}

One of the first studies analyzing the potential use of accounting ratios as predictors for insolvency was conducted by Beaver (1966). He used dichotomous classification tests to divide solvent and insolvent firms using different accounting ratios for different time periods before the event of insolvency and investigated their ability to distinguish between the two types of firms. The main drawback of this analysis was the univariate 
character of the method, because a firm was classified as being solvent when using one accounting ratio, but insolvent when using another. This problem was solved by Altman (1968) who introduced multivariate linear discriminant analysis for the segregation of solvent and insolvent firms. Altman's main finding was that firms cannot be solely described by two dichotomous states (solvent/insolvent), because he defined an area where firms could not be clearly assigned to solvent and insolvent. Companies move within a continuum of different economic states, which conforms to the generally accepted view in research (Dietrich, 1984; Ward, 1999; Turetsky \& McEwen, 2001; Kahl, 2002; Haber, 2005; Cestari, Risaliti, \& Pierotti, 2013).

Therefore, a finer granulation of different economic states was necessary and with the introduction of logistic regression by Ohlson (1980), this aspect was made possible. This method assigns an object to a group with a specific probability (R. P. Burns \& R. Burns, 2008; K. Skogsvik \& S. Skogsvik, 2013). The development of the modern rating systems is based on this model. The first attempt for a five-state model was conducted by Lau (1987). Even if the conditions were given to divide between different economic situations of a firm to a certain degree, the phenomenon of crisis remains unobservable. It is also difficult to determine the accurate thresholds between different economic states, where the different types of crises could be included, meaning that early warning instruments are somewhat limited in their forecasting ability.

There is a need for much better segregation between the different types of economic states of companies. One possible solution could be the detection of patterns, which can reveal behavioral aspects concerning the evolution of crises and insolvencies. Several studies have been conducted in this area using the application of neural networks. These provided better results when compared to discriminant analysis and logistic regression (Coats \& Fant, 1993; M. Anandarajan, Lee, \& A. Anandarajan, 2001; Charitou, Neophytou, \& Charalambous, 2004; Neves \& Vieira, 2006; Yim \& Mitchell, 2007), but this superiority was not confirmed within other studies (Fanning \& Cogger, 1994; Sen, Ghandforoush, \& Stivason, 2004; Pompe \& Bilderbeek, 2005; Chen, Marshall, Zhang, \& Ganesh, 2006).

Even if neural networks can, in certain cases, provide better classification results, it remains a black-box (Etheridge \& Sriram, 1997; Anderson, 2007), meaning that the results cannot be interpreted economically, which is an important condition for practical application and the understanding of crises in the context of the development of a crisis evolution theory. A better model for capturing the real-world situation was used by Shumway (2001), who moved away from the static viewpoint towards a dynamic model. His hazard model was able to outperform other methods as he incorporated time series and respective covariates. The economic situation of a firm depends on its previous situation, so that a certain connection between consecutive observation periods can be assumed (Dirickx \& van Landeghem, 1994).

Several other methods (such as recursive partitioning, decision trees, fuzzy logic or survival and hazard models) were used for the purpose of prediction, and in some studies, better results were obtained when compared to discriminant analysis, logistic regression, and neural networks (Anandarajan et al., 2001; Shumway, 2001; Shin, Lee, \& Kim, 2005; Min, Lee, \& Han, 2006; Yip, 2006; Cheng, Su, \& Li, 2006; Hwang, Cheng, \& Lee, 2007; Li, Sun, \& Wu, 2010; Aktan, 2011). These aspects were not confirmed within other studies (Dimitras, Slowinski, Susmaga, \& Zopounidis, 1999; Ko, Blocher, \& Lin, 2001; Min \& Lee, 2005; Chen et al., 2006; Santos, Cortez, Pereira, \& Quintela, 2006; Muller, Steyn-Bruwer, \& Hamman, 2009; Chen \& Du, 2009; Doolatabadi, Hoseini, \& Tahmasebi, 2013), and therefore, the three applications mentioned above remain the most prominent methods for the development of crises and insolvency prediction models (Du Jardin, 2009). 


\section{Studies Related to Different Economic and Financial States of Companies}

The selection of solvent and insolvent data sets used in empirical research assumes that the different economic and financial states of the firm are integrated implicitly and that a scale can be constructed (for example, a Z-score model based on linear discriminant analysis or probabilities for a company to be assigned to one of the two groups based on logistic regression) where these different states can be recognized. Such an approach does not necessarily provide an explanation of how a firm moves within this continuous scale, or which factors affect an improvement or deterioration of corporate performance respectively. As was already stated, one of the first attempts to gain a deeper insight in this area was conducted by Lau (1987). However, for certain pre-defined economic states, the prediction was difficult to make and provided unsatisfactory results (Lau, 1987). This aspect was confirmed by Chen et al. (2011) through the use of a flow-based corporate credit model, as their developed model was not working perfectly, because several states were not clearly assigned (Chen et al., 2011).

Within the study of Anyane-Ntow (1991), three groups of firms were selected for comparison using factor analysis. He concluded that there are certain underlying factors common to all of the three groups. All firms exhibited operating losses and working capital problems. Financial ratios were useful to indicate symptoms of potential failures, but they were not able to indicate the cause of these failures (Anyane-Ntow, 1991). Poston, Harmon, and Gramlich (1994) defined three states for their study. They used several versions of Z-scores in order to classify companies into different types and found that accounting ratios are of questionable value in this case, as it was not possible to make a clear distinction between them (Poston et al., 1994). A similar conclusion was made by Wilson, Chong, Peel, and Kolmogorov (1995), who compared failed, non-failed, and distressed acquired firms. It was much easier to differentiate between failed and non-failed firms, in comparison to differentiating between failed and distressed acquired firms. They concluded that the latter two types of firms appear to have similar characteristics, with the result that it is difficult to make a proper distinction between them (Wilson et al., 1995). This result was confirmed by the study of Barniv, Agarwal, and Leach (2002), although they had difficulties in identifying acquired firms (Barniv et al., 2002), which underlines the problems of a dichotomous approach in constructing prediction models. It appears that the different states in-between solvent and insolvent have certain corresponding behaviors for the firm, which makes them relatively difficult to differentiate between each other.

An investigation using Chapter 11 filings, prepacks, private and public workouts was conducted by Chatterjee, Dhillon, and Ramírez (1996). Significant differences could be detected in terms of both firm size and debt among the four restructuring methods, with the result that a prediction could be made into which of the different states a firm can be categorized (Chatterjee et al., 1996). This result was also found by Rose-Green and Lovata (2013) for reorganized and liquidated firms. The differences between distressed and recovered firms were analyzed by Whitaker (1999). He was able to show that firms in distress which have a high degree of leverage are less likely to recover. A main reason for the success of turnarounds is the corrective action taken by management, as this can significantly help a firm to recover from financial distress and to improve a firm's market value relative to its industry (Whitaker, 1999). The suitability of accounting ratios for the recognition of a distressed firm's potential to move towards bankruptcy was verified by Turetsky and McEwen (2001). Here, measurements of liquidity and financial leverage were relevant predictors in the detection of defaults, which had significant associations with business failure (Turetsky \& McEwen, 2001). These results were confirmed by the study of Tsai (2013), who analyzed slightly distressed firms, firms in reorganization or bankruptcy, and 
non-distressed firms. Financial ratios have good signaling power for firms closely related to reorganization and bankruptcy, but are not that suitable for the detection of slight distress (Tsai, 2013).

Two additional studies emphasizing the difficulties in predicting targets for corporate mergers and bankrupt/distressed firms were conducted by Sen et al. (2004) and Chancharat, Tian, Davy, McCrae, and Lodh (2010). Similarly to Wilson et al. (1995) and Barniv et al. (2002), they reached the result that the distinction between bankrupt and non-bankrupt is easier to make than a distinction between different types of mergers (Sen et al., 2004) and that a segregation between active companies and distressed takeovers, mergers, or acquisitions is difficult to make due to them having similar survival characteristics (Chancharat et al., 2010). The same results were found by Liou and Smith (2007), who applied Taffler's Z-score to identify negative failed and negative non-failed firms. The discriminant analysis model did not show good results in differentiating between the two types of firms. The results were only slightly improved when macroeconomic variables were added to financial ratios. Their conclusion is that financial ratios alone do not seem to be sufficient to discriminate between the two types of firms (Liou \& Smith, 2007).

The majority of the reviewed studies point out that making a distinction between firms that have different in-between states is much more difficult than solely differentiating between bankrupt and non-bankrupt firms. Therefore, the models which only capture data for firms with the two states of non-bankrupt and bankrupt are not able to provide explanations for the events of distress, default, turnaround, or reorganization. It is therefore necessary to have a much higher level of detail in research and to segregate the different states as much as possible, in order to get a much better insight into how the different types for firms behave. Therefore, it is also not possible to provide clear evidence about the correlational behavior of accounting ratios for solvent and insolvent firms, when correlation and factor analyses are not applied separately for each of the two groups of firms. This specific task is the main purpose of this current study.

\section{Relevance of Accounting Ratios for Prediction Purposes}

A main point of examination, in terms of the relevance of accounting ratios as predictors for firm failure, is the existence of a semi-strong market efficiency, which is the most relevant form based on empirical research (Zhang, 2006; Agarwal \& Taffler, 2008; Varamini \& Kalash, 2008). In the case of a strong form of market efficiency, there would be doubts about any attempt to develop prediction models, as based on this occurrence, no market participant could achieve superior information which could then be exploited for abnormal returns (Varamini \& Kalash, 2008; Solnik \& McLeavey, 2009). Accordingly, it is useless to develop prediction models as they do not provide additional, beneficial information to be exploited for this task. Markets are not in the position to impound information in a timely manner, with the result that a standalone view of market indicators would provide over- and under-valuation (Setiono \& Strong, 1998; Zhang, 2006; Agarwal \& Taffler, 2008; Milburn, 2008). This leads to the conclusion that accounting ratios have a certain informational content which could be beneficial in overcoming the problems of a strict market-based view of discriminating indicators.

There is some doubt about the informational content of accounting ratios, as managers and entrepreneurs can, to a certain degree, manipulate the presentation of corporate success based on generally accepted accounting principles (Keasey \& Watson, 1991; Nissim \& Penman, 2003). They do this in order to provide positive information to the public (Williamson, 1984). For managers, the incentive to disguise the real situation in which the company finds itself is based on the principal-agent theory: to convince shareholders about the good performance of the firm, as their bonuses are, in turn, linked to corporate success (Merchant \& Van der 
Stede, 2007). Therefore, under this assumption, it must be concluded that information from financial statements does not give the real economic and financial condition of a company and cannot therefore deliver appropriate discriminating variables for prediction purposes (Bernhardsen, 2001). Another argument against the application of accounting ratios as prediction variables is that they provide information about the history of the firm and do not provide indicators of future performance (Anderson, 2007; Madrid-Guijarro, Garcia-Perez-de-Lema, \& Van Auken, 2013).

This last argument does not appear to be true from an empirical standpoint, as it was shown within the study of Piotroski (2000) that accounting ratios provide informational content for some months after the issuance of the financial statement. In certain cases, this information was more effective than market data in predicting the economic and financial situations of a firm (Beaver, Kettler, \& Scholes, 1970). It was also found that accounting ratios have the potential to provide relevant information towards the prediction of financial distress and are therefore useful variables for prediction models (Kwon \& Wild, 1994), a theory which was also confirmed by the study of Turetsky and McEwen (2001).

The potential use of accounting ratios as predictors for failures is based on their inherent information content. Studies have shown that redundancies are apparent. This means that information from one accounting ratio is, to a certain degree, also included in other accounting ratios (Laurent, 1979; Chen \& Shimerda, 1981; Pohlman \& Hollinger, 1981; Anyane-Ntow, 1991). Every ratio contains individual and common information. Common information is replicated by a factor, upon which several ratios can be loaded. Such ratios share common characteristics and this indicates that they are somehow connected with each other. A piece of information from every ratio remains individual and cannot be associated with the underlying factor. The inclusion of accounting ratios within forecasting models can therefore be beneficial, as this individual information could be of relevance for an improved model performance (Laurent, 1979; Chen \& Shimerda, 1981; Pohlman \& Hollinger, 1981).

Even if research provides evidence that an insolvency prediction model should include diverse types of variables in order to improve classification accuracy (Grunert, Norden, \& Weber, 2005; Muller et al., 2009; Altman, Sabato, \& Wilson, 2010; Iazzolino, Migliano, \& Gregorace, 2013), the importance of accounting ratios still remains high. They are potential variables which can provide information about the economic situation of a firm. Additionally, results from prior research confirm that accounting ratios have a certain application for prediction purposes, as they include information which is suitable to detect potential crises and insolvencies (Kwon \& Wild, 1994; Piotroski, 2000; Turetsky \& McEwen, 2001; Chava \& Jarrow, 2004; Mohanram, 2005; Milburn, 2008; Ak, Dechow, Sun, \& Wang, 2013).

\section{Data and Methodology}

\section{Database}

The database of this study included accounting ratios from Austrian firms in different industries for the observation period from 2010 to 2012. The year 2012 was set as the insolvency date and the previous periods were defined as follows:

(1) 2011: One year prior to insolvency;

(2) 2010: Two years prior to insolvency.

The firms were divided into the states "solvent" and "insolvent”. Within the group of insolvent firms, two sub-classes were summarized. The first sub-class contains enterprises which went into bankruptcy in 2012 based 
on the legal definition of the Austrian insolvency law. The second sub-class was composed of firms exhibiting a specific indicator, the presence of which can be assumed to indicate distress. A possible definition for distress is the occurrence of negative earnings for two consecutive years. Such a definition and procedure was also used within prior research (Poston et al., 1994; Foster, Ward, \& Woodroof, 1998; H. D. Platt \& M. B. Platt, 2002; 2008; Chen et al., 2006; Molina \& Preve, 2009). Solvent firms were neither insolvent nor distressed.

In total, 1,616 firms were identified from the database, for which two consecutive financial statements were available. They can be divided into the defined groups shown in Table 1.

Table 1

Division of Firms Into the Different Economic States

\begin{tabular}{lc}
\hline Economic state & Amount \\
\hline Insolvent & 26 \\
Distressed & 70 \\
Solvent & 1,520 \\
Total & 1,616 \\
\hline
\end{tabular}

No matched pairing was applied within the study, because of a potential choice-based sampling bias (Zmijewski, 1984; Ward, 1999; H. D. Platt \& M. B. Platt, 2002; K. Skogsvik \& S. Skogsvik, 2013). In the case of paired samples, the chosen objects do not replicate the true proportions between solvent and insolvent firms, which are apparent in the real world. As insolvencies are indeed a rare event, they display certain characteristics and prior probabilities that are different to solvent cases. In order to detect these characteristics and associated patterns, it is useful to use different proportions between the two types of firms (Thomas, Edelman, \& Crook, 2002). Therefore, within this study, a proportion similar to previous studies was used (Ohlson, 1980; Zmijewski, 1984; Baetge, Beuter, \& Feidicker, 1992; Begley, Ming, \& Watts, 1996; Hillegeist, Keating, Cram, \& Lundstedt, 2004; Chaudhuri, 2013).

Based on the available data, it was possible to compute different financial ratios, which were selected due to their appearance in previous literature. Table A1 in Appendix A lists the ratios which were analyzed within this study. All of the ratios were computed for the period of one and two years prior to insolvency.

\section{Methodology and Research Design}

The purpose of this study was not to develop an early warning system. Instead, it was to analyze the correlations between the different accounting ratios for each of the two groups of firms for the time period of one and two years prior to insolvency respectively. The following procedures were conducted:

(1) Descriptive statistics were computed, in order to derive relevant measures such as mean, median, and standard deviation for the comparison between the two groups;

(2) A test of normal distribution of data was applied, in order to recognize whether a parametric or non-parametric test for differences between the two groups must be applied;

(3) Parametric tests for differences in means (t-test) and differences in variances (Levene's test) and a non-parametric test ( $U$-test) were computed, in order to detect the best discriminating variables;

(4) Several correlations (based on Pearson) were computed, in order to test the research hypothesis and to answer the research questions. The correlations were computed for: (a) insolvent firms; (b) solvent firms; and (c) all firms together. Additionally, the correlations across the time periods were computed (for example, correlation of the 2011 accounting ratios with the 2010 accounting ratios for the solvent firms, etc.); 
(5) Finally, factor analysis was applied, in order to evaluate the behavior of insolvent and solvent firms concerning their underlying factors for the accounting ratios.

It is assumed that the correlational behavior of insolvent and solvent firms varies for the different time periods prior to insolvency. The event of insolvency causes more extreme disturbances within a company and these disturbances have a much greater effect on accounting ratios. Therefore, it can be argued that the correlations between the accounting ratios should differ substantially in comparison to solvent firms. This should be visible when the relationships concerning statistically significant correlations and the values of the correlations are analyzed. Additionally, correlations should generally be different between the two groups. When, for a certain combination of accounting ratios, there are no differences in correlation values, this would imply that the related ratios are not able to explain the differences between solvent and insolvent firms. The hypothesis of this work is:

H1: Insolvent firms have different correlational behaviors one and two years prior to insolvency when compared to solvent firms.

Additionally, the following research questions shall be answered:

(1) What are the reasons why the correlational behavior of accounting ratios for insolvent and solvent firms differs for the two observation periods?

(2) How strongly is information from accounting ratios for the period two years prior to insolvency replicated in accounting ratios one year prior to insolvency?

\section{Statistical Analyses}

\section{Descriptive Statistics and Test for Normality of Data}

The results of descriptive statistics including mean, median, and standard deviation and the Kolmogorov-Smirnov significance are displayed in Table A2 in Appendix A. The first important indication is that there are no accounting ratios which showed a normal distribution at the $5 \%$ level. The null hypotheses can, in most cases, also be rejected at the $1 \%$ level. Therefore, the application of a parametric test for differences between the two groups does not seem appropriate, meaning that a non-parametric approach should deliver much better results.

A deeper analysis of descriptive statistics does not make much sense due to the high number of variables used. The results indicate that solvent firms exhibit better values when compared to insolvent firms (e.g., higher equity ratio, higher profitability, etc.), which was expected based on the results from prior studies. The main point of interest is whether these differences are statistically significant for a clearer segregation of the firms into the two defined classes.

\section{Tests for Differences Between Groups}

Table A3 in Appendix A provides the results for different tests to determine whether there are statistically significant differences at the $5 \%$ level between the two groups of firms. Due to the lack in normality of data, the results from the $U$-test are interpreted. The results from the parametric tests ( $t$-test, Levene's test) are added for informational purposes. Nineteen of the 23 ratios were statistically significant one year prior to bankruptcy, whereas 16 out 23 were significant two years prior to the event. This indicates that the signaling and discriminatory power using accounting is much higher nearer the event of insolvency (Beaver, 1966; Kwon \& Wild, 1994). 
Therefore, it is useful to extract the accounting ratios which only show discriminatory power in the first and second year prior to insolvency for further analyses. For practical purposes, it is of interest to detect crises and insolvencies as early as possible so that respective turnaround activities can be implemented much more efficiently. The ratios AGE, TD/TE, S/TA, CA/TA, SIZE I, SIZE II, CA/S, S/TE, and GP/TA were excluded and not considered for further exploration.

\section{Correlation Analysis}

When correlation analysis is computed with all types of firms together, then it is not possible to determine the contribution of each type of firm to the overall results. Therefore, within this study, the correlations were computed for each group separately and also for all firms together, which was not found to be applied in previous studies. The respective results are shown in Appendix A of this paper for one and two years prior to the event of insolvency, but also the correlations of the variables between 2011 and 2010.

The results for one and two years prior to insolvency are summarized in Table 2. There are much more statistically significant correlations for solvent firms when compared to insolvent firms. Certain variables are more strongly correlated than others and it is of interest where the differences in correlations between solvent and insolvent firms occur. For this purpose, correlations containing multicollinearity were analyzed. The threshold was set at 0.7 , as high values for correlation coefficients are an indicator for this aspect (Harris \& Sollis, 2003). The results are also highlighted in Table 2. Certain significant and high correlations two years prior to insolvency appear to change dramatically for the insolvent firms nearer the event of insolvency.

Table 2

Summary About Correlations One and Two Years Prior to Insolvency

\begin{tabular}{llcc}
\hline Period prior to insolvency & \multirow{2}{*}{ Group } & $\begin{array}{l}\text { Number of statistically } \\
\left.\left.\text { significant correlations }{ }^{*}\right)^{* *}\right)\end{array}$ & $\begin{array}{l}\text { Range for correlation } \\
\text { coefficients }\end{array}$ \\
\hline \multirow{3}{*}{ One year prior to insolvency } & \multirow{2}{*}{ All firms } & $58(29.59 \%)$ & $-1.000-0.985$ \\
& \multirow{2}{*}{ Solvent firms } & $5(2.55 \%)$ & $0.739-0.985$ \\
\cline { 2 - 4 } & \multirow{2}{*}{ Insolvent firms } & $61(31.12 \%)$ & $-1.000-0.992$ \\
& & $5(2.55 \%)$ & $0.764-0.992$ \\
\hline \multirow{3}{*}{ Two years prior to insolvency } & $36(18.37 \%)$ & $-1.000-0.988$ \\
& \multirow{2}{*}{ All firms } & $5(2.55 \%)$ & $0.739-0.988$ \\
\cline { 2 - 4 } & \multirow{2}{*}{ Solvent firms } & $52(26.53 \%)$ & $-0.999-1.000$ \\
\cline { 2 - 4 } & \multirow{2}{*}{ Insolvent firms } & $9(4.59 \%)$ & $0.876-1.000$ \\
\hline & & $49(25.00 \%)$ & $-0.998-1.000$ \\
& $10(5.10 \%)$ & $0.784-1.000$ \\
\hline
\end{tabular}

Notes. ${ }^{*}$ ) Percentages show the relation between statistically significant correlations to the total number of potential correlations. **) Second row denotes the number of detected multicollinearities and the ranges of these.

The results provide evidence that the behavior of accounting ratios (variables) and their associations to each other change when firms are in a crisis and slide into a state of insolvency. There are some remarkable differences, which are highlighted within the next paragraphs. The main reasons why correlations for insolvent firms changed were the scaling factors of total assets and sales. For example, the relation between NI/TA and NI/S shows a statistically significant correlation of 0.985 for the insolvent firms two years prior to 
insolvency. This value remained statistically significant for the period one year prior to insolvency, but decreased to the value of 0.432 . The correlation values for solvent firms were 0.076 for two years (statistically significant) and 0.042 (statistically insignificant) one year prior to insolvency. A similar pattern was visible in the relation between EBIT/TA and EBITDA/S. For the insolvent firms, the value decreased from the statistically significant value of 0.431 to the statistically insignificant value of 0.121 . Solvent firms exhibited in both years statistically significant values of 0.181 (two years prior to insolvency) and 0.167 (one year prior to insolvency).

Generally, sales and total assets, when used as a natural logarithm, replicate the size of the firm (Chi \& Tang, 2006; Chancharat et al., 2010; Pervan \& Visic, 2012; Situm, 2014). Together, they formed a separate factor within factor analysis for both types of firms two years prior to insolvency. This factor disappeared for the insolvent firms and both variables were loaded on totally separate factors. These results are highlighted within the section about factor analysis. Another aspect, which confirms this disturbance in the factor size, is that based on descriptive statistics, the relation S/TA changes remarkably for the insolvent firms. This variable had a median of 1.118 (mean: 1.557; standard deviation: 1.340 ) for the period $t-2$, whereas the value changed to 0.568 (mean: 1.417; standard deviation: 3.379). The value decreased significantly, indicating that insolvent firms are shrinking in size or more precisely, they are decreasing in sales. This decrease in assets could be related to non-observable bankruptcy costs (Herzog, Koziol, \& Thabe, 2008). Solvent firms showed stable values for median and mean for this variable, which means that they are relatively constant and are not decreasing in size.

This could be an important aspect to explain the reason why the size of the firm appeared as a potential discriminator between solvent and insolvent firms within prior studies (Ohlson, 1980; Theodossiou, Kahya, Saidi, \& Philippatos, 1996; McKee, 2007; Fitzpatrick \& Ogden, 2011). Its discriminatory power is only given for the year prior to insolvency, but not for two years prior to the event, which is undermined by the results concerning the tests for differences in means and variances. The ratios S/TA, SIZE I, and SIZE II did not show differences in any of the statistical tests for the period $t-2$, but definitively for $t-1$. Therefore, the relevance and importance of size as a prediction variable is given, as it is a differentiating variable due to the different patterns insolvent firms follow through their economic development. Nevertheless, its effective signaling power is limited, as the disturbances in size are not visible two years prior to insolvency, which would be more beneficial for early detection of corporate crises.

The correlations between 2011 and 2010 revealed very interesting insights and aspects. Based on literature, it can be concluded that there should be a connection between accounting ratios of two consecutive time periods (Dirickx \& van Landeghem, 1994; Shumway, 2001). The value of a ratio for the year 2011 depends on the value of the year 2010. Therefore, accounting ratios could be considered not only as static numbers. Rather, they are also variables, which are in the position to replicate the dynamic development of a firm as historic information is somehow included in actual ratios (Dirickx \& van Landeghem, 1994). If such an assumption is true, then correlation analysis should reveal statistically significant and high positive or negative correlations for the variables between the two years of the observation periods. The results from Table A6 in Appendix A do not support these considerations. A summary of the main aspects is provided in Table 3. 
Table 3

Summary About Correlations Between One and Two Years Prior to Insolvency

\begin{tabular}{lll}
\hline Group & Number of statistically significant correlations $\left.{ }^{*}\right)$ & $\begin{array}{l}\text { Range for correlation coefficients for statistically } \\
\text { significant correlations }\end{array}$ \\
\hline All firms & $20(10.20 \%)$ & $-0.114-0.069$ \\
Solvent firms & $33(16.84 \%)$ & $-0.135-0.179$ \\
Insolvent firms & $12(6.12 \%)$ & $0.203-0.356$ \\
\hline
\end{tabular}

Note. ${ }^{*}$ ) Percentages show the relation between statistically significant correlations to the total number of potential correlations.

Generally, the results do not support the theoretical assumptions that there are connections between the accounting ratios of two consecutive years. Thus, the second research question can be answered accordingly. The degree of information replicated from the period two years prior to bankruptcy to the first year prior to bankruptcy is very low. For the solvent firms, the highest positive correlation was found for the combination EBITDA/S to RE/TA, whereas the lowest negative correlation was given for NI/S to NI/TA. Summarized, it can be said that the connection between the two observation periods cannot be assumed and that the informational content of the period two years prior to bankruptcy is not replicated in the ratios for the period one year prior to bankruptcy.

Another pattern can be found for the insolvent firms. There are much fewer statistically significant correlations, but they have a much higher positive value compared to the solvent firms. The lowest positive correlation was given for the relation EBITDA/TA to CF/TD. The highest positive correlation was given for the relation EBT/TE to TE/TD. The obtained correlation values are slightly higher than for the solvent firms, but still not at a high level. The results indicate that historic information from the period two years prior to bankruptcy is inherent in the figures one year prior to bankruptcy to a higher degree than when compared to the solvent firms.

So, if correlations are computed for all firms together, this aspect is not visible within the figures at all. Therefore, an accurate interpretation of the behavior of correlations between the different variables cannot be properly given without separately computing the correlation for the different groups. When the figures for "all firms" would be interpreted, the same results as for the solvent ones would be found, which is strictly speaking the completely wrong approach. The researcher would not recognize that insolvent firms have a much higher connection to previous years when compared to the solvent ones. The results for both types of firms are not overwhelming, but they do indicate that solvent firms are progressing towards a hazard function, whereas insolvent firms are rather showing a kind of "pattern", which is not as hazard-like as for solvent firms.

Solvent firms can control their economic situation much better and more independently from the past situation of the firm, although solvent firms are much more dependent on their historic performance. For insolvency and crisis prediction, this is an interesting aspect, as forecasting models should therefore incorporate accounting ratios for almost two consecutive years in order to increase the incremental prediction power. If the obtained results are also valid for other samples, the incorporation of accounting ratios from the periods one and two years prior to bankruptcy should be able to improve the predictability and quality of forecasting tools. The reason behind this is that ratios for the period two years prior to bankruptcy seem to include certain information about insolvent firms, which could be exploited for better discrimination between the two types of firms. Nevertheless, the propositions of Dirickx and van Landeghem (1994) concerning the connection between accounting ratios of two consecutive periods cannot be fully confirmed with the results of this study. 
Even if the results of this study provided a divergent view in contrast to the cited work, it does not seem intuitively plausible that there is no connection between the ratios of two consecutive years. Two aspects can be named, which could affect the obtained results:

(1) Firstly, the application of correlation analysis is not the right method in order to detect the informational content between the variables for the different years. It can only explain to which degree the variables are related to each other, but the correlation values are not able to explain to which degree previous information is included in actual ratios. Therefore, there is a need for other methods which are able to measure the informational content between the two time periods;

(2) Secondly, there are some variables that are not considered or unobservable, which affect the relationship over time. As the time span covered between the two observation periods is measured in years, there could be several circumstances which disturb or even diminish a potential relationship over time. Factors such as the influence of inflation, the macroeconomic cycle, or other economic factors could create a bias in the correlations. Several studies showed that such factors are responsible for the non-stationarity of prediction models (Tirapat \& Nittayagasetwat, 1999; Nam, Kim, Park, \& Lee, 2008; Sarlija \& Jeger, 2011), which in turn can be seen as an explanation for the different correlational behaviors of solvent and insolvent firms.

\section{Factor Analysis}

The correlation analyses were complemented by the use of factor analysis in order to detect the differences in the underlying factors between solvent and insolvent firms (see Table 4). Based on the preliminary analyses, factor analysis helps to find some explanations as to why certain correlations change from one period to the other period before insolvency.

Table 4

Factor Analysis for Solvent and Insolvent Firms Two Years Prior to Insolvency

\begin{tabular}{|c|c|c|c|c|c|c|c|c|c|c|}
\hline \multirow[b]{2}{*}{ Ratios 2010} & \multicolumn{5}{|c|}{ Factors for solvent firms } & \multicolumn{5}{|c|}{ Factors for insolvent firms } \\
\hline & $\begin{array}{l}\text { Debt } \\
\text { coverage }\end{array}$ & $\begin{array}{l}\text { Long-term } \\
\text { solvency }\end{array}$ & ROI & ROS & Size & $\begin{array}{l}\text { Debt } \\
\text { coverage }\end{array}$ & ROI & $\begin{array}{l}\text { Long-term } \\
\text { solvency }\end{array}$ & Size & ROS \\
\hline Explained variance in \% ${ }^{*}$ ) & 23.916 & 42.583 & 59.856 & 74.344 & 85.010 & 24.327 & 47.914 & 67.183 & 78.565 & 89.565 \\
\hline $\mathrm{CF} / \mathrm{TD}$ & 0.959 & & & & & 0.121 & 0.953 & & 0.198 & \\
\hline NI/TA & & 0.293 & 0.859 & & & & 0.951 & & 0.221 & \\
\hline EBIT/TA & & 0.189 & 0.945 & 0.113 & & 0.880 & & & 0.148 & 0.302 \\
\hline $\mathrm{RE} / \mathrm{TA}$ & & 0.929 & 0.144 & & & & 0.383 & 0.874 & 0.162 & 0.105 \\
\hline $\mathrm{NI} / \mathrm{S}$ & & & & 0.646 & & & 0.944 & & 0.249 & \\
\hline EBITDA/S & & & & 0.958 & & 0.280 & & & & 0.878 \\
\hline EBT/TE & & -0.143 & 0.430 & & & & 0.856 & & & \\
\hline TE/TD & 0.961 & & & & & 0.446 & & 0.504 & 0.131 & -0.295 \\
\hline TE/TA & & 0.976 & & & & & & 0.986 & 0.109 & \\
\hline TD/TA & & -0.977 & & & & & & -0.986 & -0.109 & \\
\hline EBITDA/TA & & 0.141 & 0.934 & 0.123 & & 0.865 & & & & 0.367 \\
\hline EBIT/S & & & & 0.956 & & 0.460 & & & 0.238 & 0.748 \\
\hline EBITDA/TD & 0.991 & & & & & 0.953 & 0.105 & & & 0.101 \\
\hline EBIT/TD & 0.990 & & & & & 0.955 & & & & \\
\hline SIZE I & & 0.212 & & & 0.906 & 0.115 & 0.283 & 0.298 & 0.849 & 0.105 \\
\hline SIZE II & -0.100 & & & 0.159 & 0.912 & 0.152 & 0.265 & 0.128 & 0.918 & \\
\hline
\end{tabular}

Notes. ") Here the cumulated explained variance is reported. Values in bold indicate to which factor the respective ratio is assigned. ROI: Return on investment; ROS: Return on sales. Definitions of the ratios can be found in Table A1 in Appendix A. 
In general, it is difficult to assign definitions to the factors. Nevertheless, an attempt was made to do so within this work, based on the results of Laurent (1979), Chen and Shimerda (1981), and Pohlman and Hollinger (1981). The factors generally remained the same, but different variables were loaded on them and from the viewpoint of solvent firms, they moved from their "original" factors which they were loaded on to "new" factors. The variable TE/TD moved from debt coverage to the long-term solvency factor. For solvent firms, equity acts as a kind of cushion, which can be used to cover debt. This function seems to disappear for insolvent firms, because on average they have much less equity and in some cases negative equity, meaning that the coverage function of equity disappeared. Therefore, the loading of this variable changed to long-term solvency.

A similar occurrence is observable for the ratio CF/TD, which is a debt coverage ratio. For insolvent firms, it changes into the ROI factor due to a similar reason. The variable is, on average, negative for insolvent firms, meaning that the coverage function is also not given anymore. EBIT/TA and EBITDA/TA were assigned using the ROI factor, but for insolvent firms, they were classified using the debt coverage factor. The reason behind this is that the total assets of insolvent firms are composed of a very high proportion of debt, meaning that EBIT and EBITDA act as a kind of liquidity which is useful for debt coverage. Therefore, the difference between EBIT/TA and EBIT/TD as well as for EBITDA/TA and EBITDA/TD is disturbed, with the result that none of them are dispersed on two separate factors.

$\mathrm{NI} / \mathrm{S}$ also leaved its positions from the factor ROS and may be assigned to the ROI factor. Here, the ratio showed negative signs for insolvent firms on average, with the result that their role as an indicator for profitability of sales was lost. Firms with negative earnings are not profitable anymore and therefore, the main question within turnaround activities is how to restructure in order to achieve growth again (Sudarsanam \& Lai, 2001).

The size factor remains unchanged for both types of firms, which then changes for the period one year prior to insolvency (results from Table 5). This could be the explanation for why both variables related to the size of the firm did not show any discriminatory power for the period two years prior to insolvency for discrimination between the two types of firms. Even if firms are facing economic and financial problems, they do not disturb the scaling factors total assets and sales, meaning that the size of the firms is not a relevant crisis indicator two years prior to insolvency. Both variables of size are loaded on different factors for the period one year prior to insolvency. The general assumption that firms with greater size are less likely to fail can be upheld under the obtained results, because the means and medians for SIZE I and SIZE II between the two groups of firms were almost different based on tests for differences, which is in congruence with the results from prior research (Theodossiou et al., 1996; Lennox, 1999; Chava \& Jarrow, 2004).

For the period one year prior to insolvency, not only the size factor, but also the debt coverage factor disappeared. This is an appealing outcome, as insolvent firms display high liquidity problems (Turetsky \& McEwen, 2001; Min \& Lee, 2008; Bahiraie, Ibrahim, \& Azhar, 2009) and are therefore not in the position to properly repay principal and interest obligations (Nam \& Jinn, 2000; Chen et al., 2011). To provide a better interpretation, a new factor called "growth" was introduced due to the findings of Bruse (1978). Within his study, he separated growing from non-growing firms and the ratios EBT/TE appeared as a relevant discriminator for this task. As this variable showed the highest loading for both types of firms, the related factor was defined by Bruse (1978). This makes sense based on the results of descriptive statistics. On average, solvent firms exhibited higher values for this ratio when compared to insolvent firms. Insolvent firms showed 
negative values, meaning that they were destroying equity capital with results from operational business. Solvent firms exhibited positive values so that shareholder value was created, which is an indicator for company growth respectively when positive operating profits after taxes are given (Arzac, 2008; Koller, Goedhart, \& Wessels, 2010). The destruction of a firm's value when close to the point of insolvency is also visible in the reduced and negative cash flows, as well as in the increase of debt finance (Martin \& Scott, 1976; Hong \& Rappaport, 1978). A potential explanation for this occurrence could be the fact that insolvent firms are not in the position to adjust their capital structure levels due to higher transaction costs, which are caused by high debt levels (Drobetz \& Wanzenried, 2006; Pindado, Rodrigues, \& de la Torre, 2008; Liang \& Bathala, 2009).

Table 5

Factor Analysis for Solvent and Insolvent Firms One Year Prior to Insolvency

\begin{tabular}{|c|c|c|c|c|c|c|c|c|c|c|}
\hline \multirow[b]{2}{*}{ Ratios 2011} & \multicolumn{6}{|c|}{ Factors for solvent firms } & \multicolumn{4}{|c|}{ Factors for insolvent firms } \\
\hline & $\begin{array}{l}\text { Debt } \\
\text { coverage }\end{array}$ & $\begin{array}{l}\text { Long-term } \\
\text { solvency }\end{array}$ & ROI & ROS & Size & Growth & ROI & $\begin{array}{l}\text { Long-term } \\
\text { solvency }\end{array}$ & ROS & Growth \\
\hline Explained variance in \%") & 16.583 & 32.722 & 48.357 & 63.177 & 73.947 & 80.580 & 27.002 & 47.773 & 63.004 & 76.212 \\
\hline $\mathrm{CF} / \mathrm{TD}$ & 0.923 & 0.148 & & & & & 0.489 & & 0.256 & 0.724 \\
\hline NI/TA & 0.173 & 0.274 & 0.488 & 0.245 & & 0.348 & 0.644 & 0.189 & 0.204 & 0.572 \\
\hline EBIT/TA & 0.156 & & 0.952 & & & & 0.890 & 0.119 & & \\
\hline $\mathrm{RE} / \mathrm{TA}$ & & 0.798 & 0.118 & & & & & 0.983 & & \\
\hline $\mathrm{NI} / \mathrm{S}$ & & & & 0.702 & & & & & 0.933 & 0.238 \\
\hline EBITDA/S & & & 0.134 & 0.938 & & & 0.145 & & 0.548 & 0.239 \\
\hline EBT/TE & & & & & & 0.946 & & & & 0.797 \\
\hline TE/TD & 0.384 & 0.111 & -0.257 & & -0.138 & 0.105 & & 0.207 & & -0.203 \\
\hline TE/TA & 0.138 & 0.954 & & & & & & 0.992 & & \\
\hline TD/TA & -0.138 & -0.954 & & & & & & -0.992 & & \\
\hline EBITDA/TA & 0.159 & & 0.951 & & & & 0.902 & & & \\
\hline EBIT/S & & & 0.142 & 0.939 & & & & & 0.910 & \\
\hline EBITDA/TD & 0.880 & & 0.382 & & & & 0.828 & & 0.118 & 0.325 \\
\hline EBIT/TD & 0.862 & & 0.417 & & & & 0.818 & & 0.122 & 0.325 \\
\hline SIZE I & & & & & 0.920 & & 0.648 & 0.429 & 0.103 & -0.420 \\
\hline SIZE II & & & & 0.152 & 0.913 & & 0.493 & 0.305 & 0.536 & -0.253 \\
\hline
\end{tabular}

Notes. ") Here the cumulated explained variance is reported. Values in bold indicate to which factor the respective ratio is assigned. Definitions of the ratios can be found in Table A1 in Appendix A.

\section{Results and Conclusions}

It is interesting to note that the age of the firm and the ratio of retained earnings to total assets were not significantly and highly positively correlated like in certain previous studies (Frydman, Altman, \& Kao, 1985; Gilbert, Menon, \& Schwartz, 1990; Chi \& Tang, 2006; Hauser \& Booth, 2011). Therefore, within this study, this relationship could not be confirmed. The firm's age also did not show any significant and high correlation to the measurement of size, meaning that the theoretical assumption that older firms are also great in size (Jovanovic, 1982; Thornhill \& Amit, 2003) could not be confirmed. The size of the firm itself displayed the ability to distinguish between the two groups of firms for the period one year prior to insolvency, which is consistent with the results from previous studies (Theodossiou et al., 1996; Chava \& Jarrow, 2004; Situm, 2014). 
Correlation analysis revealed that there are certain significant correlations between accounting ratios of two consecutive years, but the strength of the relationship is quite low. The highest correlations were found for the insolvent firms, whose connection of the period one year prior to insolvency to the period two years prior to insolvency is much stronger than for solvent firms. This aspect indicates that the correlational behavior of solvent and insolvent firms is different. A similar conclusion can also be made for correlations of the different accounting ratios within the same year. Solvent firms exhibited more statistically significant correlations for both periods before insolvency than insolvent firms, which also indicate a different behavior between the two types of firms. Thus, the research hypothesis of this work cannot be rejected. It also answers the second research question, namely, information from the period two years prior to insolvency is rarely replicated in accounting ratios from the period one year prior to insolvency, whereas it was found that a stronger connection exists for insolvent firms (based on the results of Table 3).

The most exciting differences were detected using factor analysis, which were useful in answering the first research question about the reasons for the difference in the correlational behavior of accounting ratios for the two observation periods for the two types of firms. The variables for insolvent firms are in some cases loaded on different factors when compared to solvent firms. The effects of correlational behavior also therefore change the factor loadings, indicating that crises and the potential path to insolvency are disturbed by different factors leading to an anomaly of economic health. This means that crises cause deviations from "normal" economic behavior and imply a different pattern of evolution, which is manifested in a change of correlational behavior between the different accounting ratios and a displacement of variables concerning some common underlying factors. This aspect is only visible when correlation and factor analyses are computed for each group of firms separately. Signs of decline in economic performance seem to be much more visible when the event of insolvency is approaching (Pretorius, 2008), which was found to be the case based on the obtained results.

Assets and sales, which are used as scaling factors, change in their underlying factors for insolvent firms compared to solvent firms. This is an indicator that insolvent firms change significantly in size, which is the explanation for why size is a significant discriminating variable one year prior to insolvency. For insolvent firms, assets are mainly financed by debt, which is the cause for the shift of ratios from one factor to another. Additionally, insolvent firms show a decline in growth for the period one year prior to insolvency. The results in total provide evidence that the behaviors of solvent and insolent firms differ substantially when the event of insolvency approaches. These differences are already established for the period two years prior to the event and are much stronger one year prior to insolvency. This confirms the fact that the signaling power of accounting ratios increases as the event of insolvency approaches (Beaver, 1966; Altman, 1968; Gombola, Haskins, Ketz, \& Williams, 1987; Brabazon \& Keenan, 2004; Chi \& Tang, 2006; Muller et al., 2009).

\section{Limitations, Implications, and Recommendations for Future Research}

This study faced certain limitations, which can be summarized as follows:

(1) The proportions between failed and non-failed firms were dissimilar, in that the specific patterns of solvent firms were much better replicated than those of insolvent firms. This aspect was constructed intentionally, because in the case of model development based on empirical data, different group sizes have to be considered in order to incorporate prior probabilities of both events according to the real-world situation (Dietrich, 1984; Ward, 1999; H. D. Platt \& M. B. Platt, 2002; Anderson, 2007). Nevertheless, this aspect can have a significant influence on the results obtained in the study; 
(2) The definition and inclusion of distressed firms in the group of insolvent firms might disturb the differentiation between both types of firms, requiring a clearer distinction. Insolvent firms are characterized by the legal definition of insolvency, which is determined by insufficiency of cash flows at a time when debts fall due to be paid. Such an aspect is clearly visible in accounting figures, whereas a distressed situation might be characterized by many other significant occurrences and not only by the fact that there are two consecutive years of negative earnings (for example, with current ratio less than one (Poston et al., 1994), negative net balance in the retained earnings account (Poston et al., 1994) or when interest coverage ratio is lower than one (Jostarndt \& Sautner, 2008; Pindado et al., 2008)). It may be that the chosen benchmark for designating firms as being distressed is not appropriate enough and firms exhibiting this aspect are somehow different to truly insolvent firms. Therefore, the mixture of the two types of firms can influence correlation and factor analysis in such a way that they cannot provide more accurate results.

Taking into account these restrictions, it can nevertheless be concluded that correlation and factor analysis should be applied separately for each group of firms in order to receive a much better pattern recognition. The actual economic situation of a solvent firm showed almost no relation to the economic situation of the previous year, whereas for insolvent firms, this relation was somehow a given. Nevertheless, the strength of the dependence between the two consecutive observation periods remained at a low level. A possible conclusion of these results is that solvent firms tend to follow a hazard function, while insolvent firms are to a certain degree moving on a determined path which is dependent on the values of accounting ratios from the previous year. Two potential topics can be proposed for future research: Firstly, the search for more suitable methods should be considered which are able to exploit these aspects accordingly so that more precise and reliable forecasting models can be developed; and secondly, it could be of benefit to investigate how the informational content of accounting ratios from previous years could be amplified and used for better discrimination between solvent and insolvent firms within prediction models. This aspect could also be interesting in order to provide a better segregation of firms that exhibit different economic and financial stages in-between the two extreme conditions.

\section{References}

Agarwal, V., \& Taffler, R. (2008). Does financial distress risk drive the momentum anomaly? Financial Management, 37(3), 461-484.

Agarwal, V., \& Taffler, R. J. (2007). Twenty-five years of the Taffler z-score model: Does it really have predictive ability? Accounting and Business Research, 37(4), 285-300.

Ak, B. K., Dechow, P. M., Sun, Y., \& Wang, A. Y. (2013). The use of financial ratio models to help investors predict and interpret significant corporate events. Australian Journal of Management, 38(3), 553-598.

Aktan, S. (2011). Application of machine learning algorithms for business failure prediction. Investment Management and Financial Innovations, 8(2), 52-65.

Altman, E. I. (1968). Financial ratios, discriminant analysis, and the prediction of corporate bankruptcy. The Journal of Finance, 23(4), 589-609.

Altman, E. I., Sabato, G., \& Wilson, N. (2010). The value of non-financial information in small and medium-sized enterprise risk management. The Journal of Credit Risk, 6(2), 1-33.

Anandarajan, M., Lee, P., \& Anandarajan, A. (2001). Bankruptcy prediction of financially stressed firms: An examination of the predictive accuracy of artificial neural networks. Intelligent Systems in Accounting, Finance, and Management, 10(2), 69-81.

Anderson, R. (2007). The credit scoring toolkit: Theory and practice for retail credit risk management and decision automation. Oxford: Oxford University Press. 
Anyane-Ntow, K. (1991). Accounting information and its relationship to corporate financial distress process. The Journal of Applied Business Research, 7(3), 29-35.

Arzac, E. R. (2008). Valuation: Mergers, buyouts, and restructuring. New Jersey, NJ: John Wiliey \& Sons.

Baetge, J., Beuter, H., \& Feidicker, M. (1992). Kreditwürdigkeitsprüfung mit Diskriminanzanalyse. Die Wirtschaftsprüfung, 24, 749-761.

Bahiraie, A., Ibrahim, N. A., \& Azhar, A. K. M. (2009). On the predictability of risk box approach by genetic programming method for bankruptcy prediction. American Journal of Applied Sciences, 6(9), 1748-1757.

Barniv, R., Agarwal, A., \& Leach, R. (2002). Predicting bankruptcy resolution. Journal of Business Finance and Accounting, 29(3-4), 497-520.

Bartual, C., Garcia, F., Gimenez, V., \& Romero-Civera, A. (2012). Credit risk analysis: Reflections on the use of the logit model. Journal of Applied Finance and Banking, 2(6), 1-13.

Beaver, W. H. (1966). Financial ratios as predictors of failure. Journal of Accounting Research, 4, 71-111.

Beaver, W., Kettler, P., \& Scholes, M. (1970). The association between market determined and accounting determined risk measures. The Accounting Review, 45(4), 654-682.

Begley, J., Ming, J., \& Watts, S. (1996). Bankruptcy classification errors in the 1980s: An empirical analysis of Altman's and Ohlson's models. Review of Accounting Studies, 1(4), 267-284.

Bernhardsen, E. (2001). A model of bankruptcy prediction. Working Paper, Financial Analysis and Structure Department, Research Department. Oslo: Norges Bank.

Brabazon, A., \& Keenan, P. B. (2004). A hybrid genetic model for the prediction of corporate failure. Computational Management Science, 1, 293-310.

Bruse, H. (1978). Die Prognosefähigkeit von Kennzahlen bei verschiedenen Maßen für das Unternehmenswachstum. Zeitschrift für Betriebswirtschaft, 48, 138-152.

Burns, R. P., \& Burns, R. (2008). Business research methods and statistics using SPSS. London: Sage Publications, Ltd..

Butera, G., \& Faff, R. (2006). An integrated multi-model credit rating system for private firms. Review of Quantitative Finance and Accounting, 27(3), 311-340.

Casey, C., \& Bartczak, N. (1985). Using operating cash flow data to predict financial distress: Some extensions. Journal of Accounting Research, 23(1), 384-401.

Cestari, G., Risaliti, G., \& Pierotti, M. (2013). Bankruptcy prediction models: Preliminary thoughts on the determination of parameters for the evaluation of effectiveness and efficiency. European Scientific Journal, 9(16), 265-290.

Chalos, P. (1985). Financial distress: A comparative study of individual, model, and committee assessments. Journal of Accounting Research, 23(2), 527-543.

Chancharat, N., Tian, G., Davy, P., McCrae, M., \& Lodh, S. (2010). Multiple states of financially distressed companies: Tests using a competing-risks model. Australasian Accounting Business and Finance Journal, 4(4), 27-44.

Charitou, A., Neophytou, E., \& Charalambous, C. (2004). Predicting corporate failure: Empirical evidence for the UK. European Accounting Review, 13(3), 465-497.

Chatterjee, S., Dhillon, U. S., \& Ramírez, G. G. (1996). Resolution of financial distress: Debt restructurings via chapter 11, prepackaged bankruptcies, and workouts. Financial Management, 25(1), 5-18.

Chaudhuri, A. (2013). Bankruptcy prediction using Bayesian, hazard, mixed logit and rough Bayesian models: A comparative analysis. Computer and Information Science, 6(2), 103-125.

Chava, S., \& Jarrow, R. A. (2004). Bankruptcy prediction with industry effects. Review of Finance, 8(4), 537-569.

Chen, J., Marshall, B. R., Zhang, J., \& Ganesh, S. (2006). Financial distress prediction in China. Review of Pacific Basin Financial Markets and Policies, 9(2), 317-336.

Chen, K. H., \& Shimerda, T. A. (1981). An empirical analysis of useful financial ratios. Financial Management, 10(1), 51-60.

Chen, T. K., Liao, H. H., \& Lu, C. W. (2011). A flow-based corporate credit model. Review of Quantitative Finance and Accounting, 36(4), 517-532.

Chen, W. S., \& Du, Y. K. (2009). Using neural networks and data mining techniques for the financial distress prediction model. Expert Systems With Applications, 36(2), 4075-4086.

Cheng, W. Y., Su, E., \& Li, S. J. (2006). A financial distress pre-warning study by fuzzy regression model of TSE-listed companies. Asian Academy of Management Journal of Accounting and Finance, 2(2), 75-93.

Chi, L. C., \& Tang, T. C. (2006). Bankruptcy prediction: Application of logit analysis in export credit risks. Australian Journal of Management, 31(1), 17-27. 
Coats, P. K., \& Fant, L. F. (1993). Recognizing financial distress patterns using a neural network tool. Financial Management, 22(3), 142-155.

Dietrich, J., Arcelus, F. J., \& Srinivasan, G. (2005). Predicting financial failure: Some evidence from new Brunswick agricultural co-ops. Annals of Public and Cooperative Economics, 76(2), 179-194.

Dietrich, R. J. (1984). Discussion of methodological issues related to the estimation of financial distress prediction models. Journal of Accounting Research, 22, 83-86.

Dimitras, A. I., Slowinski, R., Susmaga, R., \& Zopounidis, C. (1999). Business failure prediction using rough sets. European Journal of Operational Research, 114(2), 263-280.

Dirickx, Y., \& van Landeghem, G. (1994). Statistical failure prevision problems. Tijdschrift voor Economie en Management, 39(4), 429-462.

Doolatabadi, H. R., Hoseini, S. M., \& Tahmasebi, R. (2013). Using decision tree model and logistic regression to predict companies financial bankruptcy in Tehran stock exchanges. International Journal of Emerging Research in Management and Technology, 2(9), 7-16.

Doumpos, M., \& Zopounidis, C. (1998). A multicriteria discrimination method for the prediction of financial distress: The case of Greece. Multinational Finance Journal, 3(2), 71-101.

Drobetz, W., \& Wanzenried, G. (2006). What determines the speed of adjustment to the target capital structure? Applied Financial Economics, 16(13), 941-958.

Du Jardin, P. (2009). Bankruptcy prediction models: How to choose the most relevant variables? Bankers, Markets, and Investors, 98, 39-46.

Etheridge, H. L., \& Sriram, R. S. (1997). A comparison of the relative costs of financial distress models: Artificial neural networks, logit, and multivariate discriminant analysis. Intelligent Systems in Accounting, Finance, and Management, 6(3), 235-248.

Fanning, K. M., \& Cogger, K. O. (1994). A comparative analysis of artificial neural networks using financial distress prediction. Intelligent Systems in Accounting, Finance, and Management, 3(4), 241-252.

Fitzpatrick, J., \& Ogden, J. P. (2011). The detection and dynamics of financial distress. International Review of Finance, 11(1), 87-121.

Foster, B. P., Ward, T. J., \& Woodroof, J. (1998). An analysis of the usefulness of debt defaults and going concern opinions in bankruptcy risk assessment. Journal of Accounting, Auditing, and Finance, 13(3), 351-371.

Frydman, H., Altman, E. I., \& Kao, D. L. (1985). Introducing recursive partitioning for financial classification: The case of financial distress. The Journal of Finance, 40(1), 269-291.

Gilbert, L. R., Menon, K., \& Schwartz, K. B. (1990). Predicting bankruptcy for firms in financial distress. Journal of Business Finance and Accounting, 17(1), 161-171.

Gombola, M. J., Haskins, M. E., Ketz, J. E., \& Williams, D. D. (1987). Cash flow in bankruptcy prediction. Financial Management, 16(4), 55-65.

Grunert, J., Norden, L., \& Weber, M. (2005). The role of non-financial factors in internal credit ratings. Journal of Banking and Finance, 29(2), 509-531.

Haber, J. R. (2005). Assessing how bankruptcy prediction models are evaluated. Journal of Business and Economics Research, 3(1), 87-92.

Harris, R., \& Sollis, R. (2003). Applied time series modelling and forecasting. West Sussex: John Wiley \& Sons.

Hauser, R. P., \& Booth, D. (2011). Predicting bankruptcy with robust logistic regression. Journal of Data Science, 9, 565-584.

Herzog, S., Koziol, C., \& Thabe, T. (2008). Optimal credit ratings. International Journal of Theoretical and Applied Finance, 11(2), 225-247.

Hillegeist, S. A., Keating, E. K., Cram, D. P., \& Lundstedt, K. G. (2004). Assessing the probability of bankruptcy. Review of Accounting Studies, 9(1), 5-34.

Hong, H., \& Rappaport, A. (1978). Debt capacity, optimal capital structure, and capital budgeting analysis. Financial Management, 7(3), 7-11.

Hwang, R. C., Cheng, K. F., \& Lee, J. C. (2007). A semiparametric method for predicting bankruptcy. Journal of Forecasting, 26(5), 317-342.

Iazzolino, G., Migliano, G., \& Gregorace, E. (2013). Evaluating intellectual capital for supporting credit risk assessment: An empirical study. Investment Management and Financial Innovations, 10(2), 44-54. 
Jones, S., \& Hensher, D. A. (2004). Predicting firm financial distress: A mixed logit model. The Accounting Review, 79(4), 1011-1038.

Jostarndt, P., \& Sautner, Z. (2008). Financial distress, corporate control, and management turnover. Journal of Banking and Finance, 32(10), 2188-2204.

Jovanovic, B. (1982). Selection and the evolution of industry. Econometrica, 50(3), 649-670.

Kahl, M. (2002). Economic distress, financial distress, and dynamic liquidation. The Journal of Finance, 57(1), 135-168.

Keasey, K., \& Watson, R. (1991). Financial distress prediction models: A review of their usefulness. British Journal of Management, 2(2), 89-102.

Ko, L. J., Blocher, E. J., \& Lin, P. P. (2001). Prediction of corporate financial distress: An application of the composite rule induction system. The International Journal of Digital Accounting Research, 1(1), 69-85.

Koller, T., Goedhart, M., \& Wessels, D. (2010). Valuation: Measuring and managing the value of companies. New Jersey, NJ: John Wiley \& Sons.

Kwon, S. S., \& Wild, J. J. (1994). Informativeness of annual reports for firms in financial distress. Contemporary Accounting Research, 11(1), 331-351.

Laitinen, E. K., \& Laitinen, T. (2000). Bankruptcy prediction: Application of the Taylor's expansion in logistic regression. International Review of Financial Analysis, 9(4), 327-349.

Lau, A. H. L. (1987). A five-state financial distress prediction model. Journal of Accounting Research, 25(1), 127-138.

Laurent, C. R. (1979). Improving the efficiency and effectiveness of financial ratio analysis. Journal of Business Finance and Accounting, 6(3), 401-413.

Lennox, C. (1999). Identifying failing companies: A re-evaluation of the logit, probit, and DA approaches. Journal of Economics and Business, 51(4), 347-364.

Li, H., \& Sun, J. (2011). Empirical research of hybridizing principal component analysis with multivariate discriminant analysis and logistic regression for business failure prediction. Expert Systems With Applications, 38(5), 6244-6253.

Li, H., Sun, J., \& Wu, J. (2010). Predicting business failure using classification and regression tree: An empirical comparison with popular classical statistical methods and top classification mining methods. Expert Systems With Applications, 37(8), 5895-5904.

Liang, H. Y., \& Bathala, C. (2009). Tradeoff or pecking order: Capital structure policy suitable for financially distressed firms. The IUP Journal of Applied Finance, 15(10), 5-18.

Lin, F., Yeh, C. C., \& Lee, M. Y. (2013). A hybrid business failure prediction model using locally linear embedding and support vector machines. Romanian Journal of Economic Forecasting, 16(1), 82-97.

Liou, D. K., \& Smith, M. (2007). Macroeconomic variables and financial distress. Journal of Accounting, Business, and Management, 14, 17-31.

Madrid-Guijarro, A., Garcia-Perez-de-Lema, D., \& Van Auken, H. (2013). An investigation of Spanish SME innovation during different economic conditions. Journal of Small Business Management, 51(4), 578-601.

Marchesini, R., Perdue, G., \& Bryan, V. (2004). Applying bankruptcy prediction models to distressed high yield bond issues. The Journal of Fixed Income, 13(4), 50-56.

Martin, J. D., \& Scott, D. F. (1976). Debt capacity and the capital budgeting decision. Financial Management, 5(2), 7-14.

McKee, T. E. (2007). Altman's 1968 bankruptcy prediction model revisited via genetic programming: New wine from an old bottle or a better fermentation process? Journal of Emerging Technologies in Accounting, 4(1), 87-101.

Merchant, K., \& Van der Stede, W. (2007). Management control systems: Performance measurement, evaluation, and incentives. Essex: Pearson.

Milburn, J. A. (2008). The relationship between fair value, market value, and efficient markets. Accounting Perspectives, 7(4), 293-316.

Min, J. H., \& Lee, Y. C. (2005). Bankruptcy prediction using support vector machine with optimal choice of kernel function parameters. Expert Systems With Applications, 28(4), 603-614.

Min, J. H., \& Lee, Y. C. (2008). A practical approach to credit scoring. Expert Systems With Applications, 35(4), 1762-1770.

Min, S. H., Lee, J., \& Han, I. (2006). Hybrid genetic algorithms and support vector machines for bankruptcy prediction. Expert Systems With Applications, 31(3), 652-660.

Mohanram, P. S. (2005). Separating winners from losers among low book-to-market stocks using financial statement analysis. Review of Accounting Studies, 10(2-3), 133-170. 
Molina, C. A., \& Preve, L. A. (2009). Trade receivables policy of distressed firms and its effect on the costs of financial distress. Financial Management, 38(3), 663-686.

Muller, G. H., Steyn-Bruwer, B. W., \& Hamman, W. D. (2009). Predicting financial distress of companies listed on JSE-A comparison of techniques. South African Journal of Business Management, 40(1), 21-32.

Nam, C. W., Kim, T. S., Park, N. J., \& Lee, H. K. (2008). Bankruptcy prediction using a discrete-time duration model incorporating temporal and macroeconomic dependencies. Journal of Forecasting, 27(6), 493-506.

Nam, J. H., \& Jinn, T. (2000). Bankruptcy prediction: Evidence from Korean listed companies during the IMF crisis. Journal of International Financial Management and Accounting, 11(3), 178-197.

Neves, J. C., \& Vieira, A. (2006). Improving bankruptcy prediction with hidden layer learning vector quantization. European Accounting Review, 15(2), 253-271.

Nissim, D., \& Penman, S. H. (2003). Financial statement analysis of leverage and how it informs about profitability and price-to-book ratios. Review of Accounting Studies, 8(4), 531-560.

Ohlson, J. A. (1980). Financial ratios and the probabilistic prediction of bankruptcy. Journal of Accounting Research, 18(1), 109-131.

Pervan, M., \& Visic, J. (2012). Influence of firms size on its business success. Croatian Operational Research Review, 3(1), 213-223.

Pindado, J., Rodrigues, L., \& de la Torre, C. (2008). Estimating financial distress likelihood. Journal of Business Research, 61(9), 995-1003.

Piotroski, J. D. (2000). Value investing: The use of historical financial statement information to separate winners from losers. Journal of Accounting Research, 38, 1-41.

Platt, H. D., \& Platt, M. B. (2002). Predicting corporate financial distress: Reflections on choice-based sample bias. Journal of Economics and Finance, 26(2), 184-199.

Platt, H. D., \& Platt, M. B. (2008). Financial distress comparison across three global regions. Journal of Risk and Financial Management, 1(1), 129-162.

Pohlman, R. A., \& Hollinger, R. D. (1981). Information redundancy in sets of financial ratios. Journal of Business Finance and Accounting, 8(4), 511-528.

Pompe, P. P., \& Bilderbeek, J. (2005). Bankruptcy prediction: The influence of the year prior to failure selected for model building and the effects in a period of economic decline. Intelligent Systems in Accounting, Finance, and Management, 13(2), 95-112.

Poston, K. M., Harmon, W. K., \& Gramlich, J. D. (1994). A test of financial ratios as predictors of turnaround versus failure among financially distressed firms. Journal of Applied Business Research, 10(1), 41-56.

Pretorius, M. (2008). Critical variables of business failure: A review and classification framework. South African Journal of Economic and Management Sciences, 11(4), 408-430.

Rose-Green, E., \& Lovata, L. (2013). The relationship between firm's characteristics in the periods prior to bankruptcy filing and bankruptcy outcome. Accounting and Finance Research, 2(1), 97-109.

Santos, M. F., Cortez, P., Pereira, J., \& Quintela, H. (2006). Corporate bankruptcy prediction using data mining techniques. WIT Transactions of Information and Communication Technologies, 37, 349-357.

Sarlija, N., \& Jeger, M. (2011). Comparing financial distress prediction models before and during recession. Croatian Operational Research Review, 2, 133-142.

Sen, T. K., Ghandforoush, P., \& Stivason, C. T. (2004). Improving prediction of neural networks: A study of two financial prediction tasks. Journal of Applied Mathematics and Decision Sciences, 8(4), 219-233.

Setiono, B., \& Strong, N. (1998). Predicting stock returns using financial statement information. Journal of Business Finance and Accounting, 25(5-6), 631-657.

Shah, J. R., \& Murtaza, M. B. (2000). A neural network based clustering procedure for bankruptcy prediction. American Business Review, 18(2), 80-86.

Shin, K. S., Lee, T. S., \& Kim, H. J. (2005). An application of support vector machines in bankruptcy prediction model. Expert Systems With Applications, 28(1), 127-135.

Shumway, T. (2001). Forecasting bankruptcy more accurately: A simple hazard model. The Journal of Business, 74(1), 101-124.

Situm, M. (2014). The age and the size of the firm as relevant predictors for bankruptcy. Journal of Applied Economics and Business, 2(1), 5-30. 
Skogsvik, K., \& Skogsvik, S. (2013). On the choice based sample bias in probabilistic bankruptcy prediction. Investment Management and Financial Innovation, 10(1), 29-37.

Solnik, B., \& McLeavey, D. (2009). Global investments. Boston: Pearson Education, Inc..

Sudarsanam, S., \& Lai, J. (2001). Corporate financial distress and turnaround strategies: An empirical analysis. British Journal of Management, 12(3), 183-199.

Theodossiou, P., Kahya, E., Saidi, R., \& Philippatos, G. (1996). Financial distress and corporate acquisitions: Further empirical evidence. Journal of Business Finance and Accounting, 23(5-6), 699-719.

Thomas, L. C., Edelman, D. B., \& Crook, J. N. (2002). Credit scoring and its applications. Philadelphia, PA: Society for Industrial and Applied Mathematics.

Thornhill, S., \& Amit, R. (2003). Learning about failure: Bankruptcy, firm age, and the resource-based view. Organization Science, 14(5), 497-509.

Tirapat, S., \& Nittayagasetwat, A. (1999). An investigation of Thai listed firms’ financial distress using macro and micro variables. Multinational Finance Journal, 3(2), 103-125.

Tsai, B. H. (2013). An early warning system of financial distress using multinomial logit models and a bootstrapping approach. Emerging Markets Finance and Trade, 49(2), 43-69.

Turetsky, H. F., \& McEwen, R. A. (2001). An empirical investigation of firm longevity: A model of the ex ante predictors of financial distress. Review of Quantitative Finance and Accounting, 16(4), 323-343.

Varamini, H., \& Kalash, S. (2008). Testing market efficiency for different market capitalization funds. American Journal of Business, 23(2), 17-28.

Ward, T. J. (1999). A review of financial distress research methods and recommendations for future research. Academy of Accounting and Financial Studies Journal, 3(1), 160-178.

Whitaker, R. B. (1999). The early stages of financial distress. Journal of Economics and Finance, 23(2), 123-132.

Williamson, R. W. (1984). Evidence on the selective reporting of financial ratios. The Accounting Review, 59(2), $296-299$.

Wilson, N., Chong, K. S., Peel, M. J., \& Kolmogorov, A. N. (1995). Neural network simulation and the prediction of corporate outcomes: Some empirical findings. International Journal of the Economics of Business, 2(1), 31-50.

Yim, J., \& Mitchell, H. (2007). Predicting financial distress in the Australian financial service industry. Australian Economic Papers, 46(4), 375-388.

Yip, A. Y. N. (2006). Business failure prediction: A case-based reasoning approach. Review of Pacific Basin Financial Markets and Policies, 9(3), 491-508.

Zhang, X. F. (2006). Information uncertainty and stock returns. The Journal of Finance, 61(1), 105-136.

Zmijewski, M. E. (1984). Methodological issues related to the estimation of financial distress prediction models. Journal of Accounting Research, 22, 59-82. 


\section{Appendix A}

Table A1

Accounting Ratios as Potential Discrimination Variables Between Solvent and Insolvent Firms

\begin{tabular}{|c|c|c|}
\hline Ratio & Equation & Reference \\
\hline AGE & Age of the firm in years & $\begin{array}{l}\text { Chi and Tang (2006); Chancharat } \\
\text { et al. (2010) }\end{array}$ \\
\hline CF/TD & (Net income + depreciation)/total debt & $\begin{array}{l}\text { Beaver (1966); Frydman et al. } \\
\text { (1985); and Dietrich, Arcelus, and } \\
\text { Srinivasan (2005) }\end{array}$ \\
\hline NI/TA & Net income/total assets & $\begin{array}{l}\text { Beaver (1966); Ohlson (1980); and } \\
\text { Chava and Jarrow (2004) }\end{array}$ \\
\hline EBIT/TA & Earnings before interest and taxes/total assets & $\begin{array}{l}\text { Altman (1968); Grunert et al. } \\
\text { (2005); and Iazzolino et al. (2013) }\end{array}$ \\
\hline S/TA & Sales/total assets & $\begin{array}{l}\text { Altman (1968); Bartual, Garcia, } \\
\text { Gimenez, and Romero-Civera } \\
\text { (2012) }\end{array}$ \\
\hline $\mathrm{RE} / \mathrm{TA}$ & Retained earnings/total assets & $\begin{array}{l}\text { Altman (1968); Altman et al. } \\
\text { (2010); and Iazzolino et al. (2013) }\end{array}$ \\
\hline $\mathrm{NI} / \mathrm{S}$ & Net income/sales & $\begin{array}{l}\text { Chalos (1985); Shah and Murtaza } \\
(2000)\end{array}$ \\
\hline CA/TA & Cash/total assets & $\begin{array}{l}\text { Casey and Bartczak (1985); Poston } \\
\text { et al. (1994); and Altman et al. } \\
(2010)\end{array}$ \\
\hline SIZE I & Ln(Total assets) & $\begin{array}{l}\text { Grunert et al. (2005); Chi and } \\
\text { Tang (2006); and Situm (2014) } \\
\end{array}$ \\
\hline EBITDA/S & $\begin{array}{l}\text { Earnings before interest, taxes, depreciation, and } \\
\text { amortization/sales }\end{array}$ & H. D. Platt and M. B. Platt (2002) \\
\hline SIZE II & 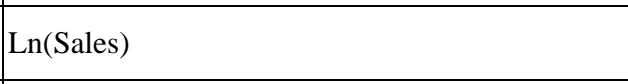 & $\begin{array}{l}\text { Chancharat et al. (2010); Situm } \\
(2014)\end{array}$ \\
\hline $\mathrm{CA} / \mathrm{S}$ & Cash/sales & Brabazon and Keenan (2004) \\
\hline $\mathrm{EBT} / \mathrm{TE}$ & Earnings before taxes/total equity & \begin{tabular}{|l} 
Bruse (1978); Pompe and \\
Bilderbeek (2005); and Sarlija and \\
Jeger (2011)
\end{tabular} \\
\hline S/TE & Sales/total equity & Bruse (1978) \\
\hline $\mathrm{TD} / \mathrm{TE}$ & Total debt/total equity & $\begin{array}{l}\text { Casey and Bartczak (1985); Jones } \\
\text { and Hensher (2004); and Chi and } \\
\text { Tang (2006) }\end{array}$ \\
\hline TE/TD & Total equity/total debt & $\begin{array}{l}\text { Dietrich et al. (2005); Bahiraie et al. } \\
(2009)\end{array}$ \\
\hline TE/TA & Total equity/total assets & $\begin{array}{l}\text { E. K. Laitinen and T. Laitinen } \\
\text { (2000); Grunert et al. (2005); and } \\
\text { Bartual et al. (2012) }\end{array}$ \\
\hline $\mathrm{TD} / \mathrm{TA}$ & Total debt/total assets & $\begin{array}{l}\text { Shah and Murtaza (2000); } \\
\text { Brabazon and Keenan (2004); and } \\
\text { Molina and Preve (2009) } \\
\end{array}$ \\
\hline EBITDA/TA & $\begin{array}{l}\text { Earnings before interest, taxes, depreciation, and } \\
\text { amortization/total assets }\end{array}$ & Altman et al. (2010) \\
\hline EBIT/S & Earnings before interest and taxes/sales & $\begin{array}{l}\text { Sudarsanam and Lai (2001); } \\
\text { Marchesini, Perdue, and Bryan } \\
(2004)\end{array}$ \\
\hline EBITDA/TD & $\begin{array}{l}\text { Earnings before interest, taxes, depreciation, and } \\
\text { amortization/total debt }\end{array}$ & Sudarsanam and Lai (2001) \\
\hline GP/TA & Gross profit/total assets & Doumpos and Zopounidis (1998) \\
\hline EBIT/TD & Earnings before interest and taxes/total debt & $\begin{array}{l}\text { Sudarsanam and Lai (2001); } \\
\text { Charitou et al. (2004) }\end{array}$ \\
\hline
\end{tabular}


Table A2

Descriptive Statistics and Test for Normality for Accounting Ratios

\begin{tabular}{|c|c|c|c|c|c|c|c|c|c|}
\hline \multirow{3}{*}{ Ratio } & \multirow{3}{*}{ Group } & \multicolumn{4}{|c|}{2011} & \multicolumn{4}{|c|}{2010} \\
\hline & & \multirow{2}{*}{$\begin{array}{l}\begin{array}{l}\text { Test for } \\
\text { normal } \\
\text { distribution }\end{array} \\
\text { KS-statistic }\end{array}$} & \multicolumn{3}{|c|}{ Descriptive statistics } & \multirow{2}{*}{$\begin{array}{l}\begin{array}{l}\text { Test for } \\
\text { normal } \\
\text { distribution }\end{array} \\
\text { KS-statistic }\end{array}$} & \multicolumn{3}{|c|}{ Descriptive statistics } \\
\hline & & & Mean & Median & Std. dev. & & Mean & Median & Std. dev. \\
\hline \multirow{2}{*}{ AGE } & Insolvent & 0.000 & 22.146 & 13.500 & 21.679 & 0.000 & 21.146 & 12.500 & 21.679 \\
\hline & Solvent & 0.000 & 24.128 & 13.500 & 27.939 & 0.000 & 23.128 & 12.500 & 27.939 \\
\hline \multirow{2}{*}{ CF/TD } & Insolvent & 0.000 & -0.205 & -0.005 & 1.302 & 0.000 & -0.041 & 0.019 & 0.929 \\
\hline & Solvent & 0.000 & 0.231 & 0.116 & 0.835 & 0.000 & 0.281 & 0.118 & 1.741 \\
\hline \multirow{2}{*}{ NI/TA } & Insolvent & 0.000 & -0.175 & -0.040 & 0.543 & 0.000 & -0.079 & -0.017 & 0.504 \\
\hline & Solvent & 0.000 & 0.039 & 0.029 & 0.165 & 0.000 & 0.049 & 0.034 & 0.166 \\
\hline \multirow{2}{*}{ EBIT/TA } & Insolvent & 0.000 & -0.089 & -0.009 & 0.282 & 0.000 & 0.002 & 0.001 & 0.107 \\
\hline & Solvent & 0.000 & 0.069 & 0.045 & 0.320 & 0.000 & 0.063 & 0.043 & 0.175 \\
\hline \multirow{2}{*}{ S/TA } & Insolvent & 0.000 & 1.417 & 0.568 & 3.379 & 0.000 & 1.557 & 1.118 & 1.340 \\
\hline & Solvent & 0.000 & 1.399 & 0.915 & 2.896 & 0.000 & 1.379 & 0.990 & 1.353 \\
\hline \multirow{2}{*}{ RE/TA } & Insolvent & 0.000 & -0.666 & -0.002 & 4.116 & 0.000 & -0.228 & 0.008 & 1.321 \\
\hline & Solvent & 0.000 & 0.075 & 0.080 & 0.436 & 0.000 & 0.091 & 0.106 & 0.547 \\
\hline \multirow{2}{*}{$\mathrm{NI} / \mathrm{S}$} & Insolvent & 0.000 & -3.445 & -0.065 & 17.321 & 0.000 & -0.171 & -0.014 & 1.359 \\
\hline & Solvent & 0.000 & -0.619 & 0.034 & 22.182 & 0.000 & 0.043 & 0.035 & 9.767 \\
\hline \multirow{2}{*}{$\mathrm{CA} / \mathrm{TA}$} & Insolvent & 0.000 & 0.091 & 0.016 & 0.159 & 0.000 & 0.046 & 0.019 & 0.065 \\
\hline & Solvent & 0.000 & 0.089 & 0.029 & 0.134 & 0.000 & 0.082 & 0.030 & 0.128 \\
\hline \multirow{2}{*}{ SIZE I } & Insolvent & 0.013 & 15.309 & 15.561 & 2.345 & 0.000 & 16.300 & 16.257 & 1.771 \\
\hline & Solvent & 0.000 & 15.873 & 15.914 & 1.684 & 0.000 & 16.370 & 16.224 & 1.684 \\
\hline \multirow{2}{*}{ EBITDA/S } & Insolvent & 0.000 & -0.622 & 0.048 & 4.084 & 0.000 & 0.066 & 0.039 & 0.187 \\
\hline & Solvent & 0.000 & 0.067 & 0.110 & 1.467 & 0.000 & 0.075 & 0.096 & 1.444 \\
\hline \multirow{2}{*}{ SIZE II } & Insolvent & 0.003 & 14.517 & 15.073 & 2.635 & 0.000 & 16.336 & 16.297 & 2.015 \\
\hline & Solvent & 0.000 & 15.555 & 15.635 & 1.820 & 0.000 & 16.146 & 16.061 & 1.659 \\
\hline \multirow{2}{*}{ CA/S } & Insolvent & 0.000 & 0.585 & 0.033 & 2.078 & 0.000 & 0.049 & 0.018 & 0.097 \\
\hline & Solvent & 0.000 & 1.147 & 0.034 & 21.246 & 0.000 & 0.213 & 0.032 & 1.506 \\
\hline FRT/TF & Insolvent & 0.000 & 0.072 & -0.021 & 1.609 & 0.000 & -0.053 & -0.031 & 1.488 \\
\hline ЕВ1/1Е & Solvent & 0.000 & 0.307 & 0.121 & 7.519 & 0.000 & 0.437 & 0.141 & 7.214 \\
\hline $\mathrm{S} / \mathrm{TE}$ & Insolvent & 0.000 & -123.102 & 2.459 & $1,367.715$ & 0.000 & 9.031 & 3.681 & 44.645 \\
\hline $\mathrm{S} / 1 \mathrm{E}$ & Solvent & 0.000 & 17.076 & 1.351 & 290.755 & 0.000 & 16.974 & 2.909 & 208.488 \\
\hline & Insolvent & 0.000 & 1.172 & 1.351 & 66.932 & 0.000 & 4.053 & 2.575 & 22.108 \\
\hline TD/TE & Solvent & 0.000 & 7.820 & 1.851 & 83.491 & 0.000 & 7.175 & 1.920 & 92.421 \\
\hline & Insolvent & 0.000 & 0.801 & 0.204 & 2.192 & 0.000 & 0.401 & 0.257 & 0.581 \\
\hline TE/TD & Solvent & 0.000 & 3.420 & 0.363 & 39.919 & 0.000 & 5.668 & 0.409 & 123.558 \\
\hline TE/TA & Insolvent & 0.000 & -0.236 & 0.170 & 3.125 & 0.000 & 0.083 & 0.204 & 1.056 \\
\hline IE/IA & Solvent & 0.000 & 0.284 & 0.266 & 0.381 & 0.000 & 0.299 & 0.290 & 0.496 \\
\hline & Insolvent & 0.000 & 1.236 & 0.830 & 3.125 & 0.000 & 0.917 & 0.796 & 1.056 \\
\hline TD/TA & Solvent & 0.000 & 0.716 & 0.733 & 0.381 & 0.000 & 0.702 & 0.710 & 0.499 \\
\hline & Insolvent & 0.000 & -0.032 & 0.033 & 0.285 & 0.000 & 0.046 & 0.040 & 0.113 \\
\hline ЕВITDA/TA & Solvent & 0.000 & 0.120 & 0.097 & 0.323 & 0.000 & 0.107 & 0.085 & 0.180 \\
\hline FRIT/S & Insolvent & 0.000 & -2.148 & -0.018 & 14.342 & 0.000 & -0.007 & 0.001 & 0.133 \\
\hline EBI1/S & Solvent & 0.000 & -0.026 & 0.049 & 1.459 & 0.000 & 0.010 & 0.048 & 1.442 \\
\hline & Insolvent & 0.000 & -0.032 & 0.031 & 0.479 & 0.000 & 0.078 & 0.049 & 0.232 \\
\hline EBITDA/TD & Solvent & 0.000 & 0.261 & 0.137 & 0.917 & 0.000 & 0.323 & 0.123 & 4.375 \\
\hline & Insolvent & 0.000 & 2.207 & 0.736 & 6.603 & 0.000 & 2.251 & 1.323 & 2.269 \\
\hline GP/IA & Solvent & 0.000 & 2.024 & 1.066 & 5.112 & 0.000 & 2.029 & 1.119 & 2.436 \\
\hline & Insolvent & 0.000 & -0.109 & -0.013 & 0.479 & 0.000 & 0.019 & 0.002 & 0.212 \\
\hline ЕВIT/ТD & Solvent & 0.000 & 0.162 & 0.062 & 0.853 & 0.000 & 0.242 & 0.060 & 4.372 \\
\hline
\end{tabular}


Table A3

Tests for Differences Between Solvent and Insolvent Firms

\begin{tabular}{|c|c|c|c|c|c|c|c|}
\hline \multirow{2}{*}{ Ratio } & \multirow{2}{*}{ Group } & \multicolumn{3}{|c|}{2011} & \multicolumn{3}{|c|}{2010} \\
\hline & & $t$-test & Levene's test & $U$-test & $t$-test & Levene's test & $U$-test \\
\hline AGE & $\begin{array}{l}\text { Insolvent } \\
\text { Solvent }\end{array}$ & 0.495 & 0.149 & 0.971 & 0.495 & 0.149 & 0.971 \\
\hline CF/TD & $\begin{array}{l}\text { Insolvent } \\
\text { Solvent } \\
\end{array}$ & 0.000 & 0.078 & 0.000 & 0.073 & 0.622 & 0.000 \\
\hline NI/TA & $\begin{array}{l}\text { Insolvent } \\
\text { Solvent } \\
\end{array}$ & 0.000 & 0.000 & 0.000 & 0.000 & 0.001 & 0.000 \\
\hline EBIT/TA & $\begin{array}{l}\text { Insolvent } \\
\text { Solvent } \\
\end{array}$ & 0.000 & 0.066 & 0.000 & 0.001 & 0.337 & 0.000 \\
\hline S/TA & $\begin{array}{l}\text { Insolvent } \\
\text { Solvent }\end{array}$ & 0.953 & 0.210 & 0.003 & 0.212 & 0.387 & 0.133 \\
\hline $\mathrm{RE} / \mathrm{TA}$ & $\begin{array}{l}\text { Insolvent } \\
\text { Solvent }\end{array}$ & 0.000 & 0.000 & 0.000 & 0.000 & 0.000 & 0.000 \\
\hline $\mathrm{NI} / \mathrm{S}$ & $\begin{array}{l}\text { Insolvent } \\
\text { Solvent }\end{array}$ & 0.221 & 0.044 & 0.000 & 0.830 & 0.688 & 0.000 \\
\hline CA/TA & $\begin{array}{l}\text { Insolvent } \\
\text { Solvent }\end{array}$ & 0.878 & 0.130 & 0.268 & 0.007 & 0.000 & 0.038 \\
\hline SIZE I & $\begin{array}{l}\text { Insolvent } \\
\text { Solvent }\end{array}$ & 0.002 & 0.000 & 0.028 & 0.691 & 0.607 & 0.956 \\
\hline EBITDA/S & $\begin{array}{l}\text { Insolvent } \\
\text { Solvent }\end{array}$ & 0.000 & 0.000 & 0.000 & 0.950 & 0.559 & 0.000 \\
\hline SIZE II & $\begin{array}{l}\text { Insolvent } \\
\text { Solvent }\end{array}$ & 0.000 & 0.000 & 0.000 & 0.284 & 0.086 & 0.242 \\
\hline $\mathrm{CA} / \mathrm{S}$ & $\begin{array}{l}\text { Insolvent } \\
\text { Solvent }\end{array}$ & 0.796 & 0.611 & 0.885 & 0.287 & 0.115 & 0.005 \\
\hline EBT/TE & $\begin{array}{l}\text { Insolvent } \\
\text { Solvent }\end{array}$ & 0.759 & 0.791 & 0.000 & 0.506 & 0.558 & 0.000 \\
\hline $\mathrm{S} / \mathrm{TE}$ & $\begin{array}{l}\text { Insolvent } \\
\text { Solvent }\end{array}$ & 0.002 & 0.000 & 0.000 & 0.709 & 0.596 & 0.497 \\
\hline $\mathrm{TD} / \mathrm{TE}$ & $\begin{array}{l}\text { Insolvent } \\
\text { Solvent }\end{array}$ & 0.445 & 0.911 & 0.228 & 0.741 & 0.622 & 0.271 \\
\hline TE/TD & $\begin{array}{l}\text { Insolvent } \\
\text { Solvent }\end{array}$ & 0.521 & 0.295 & 0.015 & 0.676 & 0.471 & 0.000 \\
\hline TE/TA & $\begin{array}{l}\text { Insolvent } \\
\text { Solvent } \\
\end{array}$ & 0.000 & 0.000 & 0.014 & 0.000 & 0.062 & 0.000 \\
\hline TD/TA & $\begin{array}{l}\text { Insolvent } \\
\text { Solvent }\end{array}$ & 0.000 & 0.000 & 0.014 & 0.000 & 0.062 & 0.000 \\
\hline EBITDA/TA & $\begin{array}{l}\text { Insolvent } \\
\text { Solvent }\end{array}$ & 0.000 & 0.138 & 0.000 & 0.001 & 0.319 & 0.000 \\
\hline EBIT/S & $\begin{array}{l}\text { Insolvent } \\
\text { Solvent }\end{array}$ & 0.000 & 0.000 & 0.000 & 0.908 & 0.507 & 0.000 \\
\hline EBITDA/TD & $\begin{array}{l}\text { Insolvent } \\
\text { Solvent }\end{array}$ & 0.002 & 0.317 & 0.000 & 0.584 & 0.531 & 0.000 \\
\hline GP/TA & $\begin{array}{l}\text { Insolvent } \\
\text { Solvent }\end{array}$ & 0.739 & 0.144 & 0.005 & 0.385 & 0.792 & 0.118 \\
\hline EBIT/TD & $\begin{array}{l}\text { Insolvent } \\
\text { Solvent }\end{array}$ & 0.002 & 0.609 & 0.000 & 0.618 & 0.550 & 0.000 \\
\hline
\end{tabular}

Note. Values in bold denote statistically significant differences at the $5 \%$ level. 
Table A4

Correlations One Year Prior to Insolvency

\begin{tabular}{|c|c|c|c|c|c|c|c|c|c|c|c|c|c|c|c|}
\hline Ratio & Group & CF/TD & NI/TA & EBIT/TA & RE/TA & $\mathrm{NI} / \mathrm{S}$ & EBITDA/S & EBT/TE & $\mathrm{TE} / \mathrm{TD}$ & TE/TA & TD/TA & EBITDA/TA & A EBIT/S & EBITDA/TD & EBIT/TD \\
\hline & All firms & 1.000 & 0.471 & 0.172 & 0.085 & 0.058 & 0.195 & 0.038 & 0.257 & 0.102 & -0.102 & 0.181 & 0.095 & 0.769 & 0.739 \\
\hline \multirow[t]{3}{*}{ CF/TD } & Solvent firms & 1.000 & 0.357 & 0.143 & 0.164 & 0.024 & 0.153 & 0.030 & 0.277 & 0.239 & -0.239 & 0.151 & 0.153 & 0.798 & 0.764 \\
\hline & Insolvent firms & 1.000 & 0.876 & 0.394 & 0.024 & 0.467 & 0.333 & 0.494 & -0.211 & -0.034 & 0.034 & 0.417 & 0.079 & 0.647 & 0.626 \\
\hline & All firms & 0.471 & 1.000 & 0.433 & 0.244 & 0.089 & 0.293 & 0.131 & 0.000 & 0.198 & -0.198 & 0.418 & 0.170 & 0.272 & 0.284 \\
\hline \multirow[t]{3}{*}{ NI/TA } & Solvent firms & 0.357 & 1.000 & 0.431 & 0.280 & 0.042 & 0.287 & 0.153 & -0.006 & 0.194 & -0.194 & 0.418 & 0.301 & 0.277 & 0.291 \\
\hline & Insolvent firms & 0.876 & 1.000 & 0.693 & 0.220 & 0.432 & 0.269 & 0.431 & 0.028 & 0.183 & -0.183 & 0.663 & 0.096 & 0.599 & 0.583 \\
\hline & All firms & 0.172 & 0.433 & 1.000 & 0.093 & 0.026 & 0.158 & 0.078 & -0.009 & 0.063 & -0.063 & 0.985 & 0.099 & 0.482 & 0.516 \\
\hline \multirow[t]{3}{*}{ EBIT/TA } & Solvent firms & 0.143 & 0.431 & 1.000 & 0.104 & 0.016 & 0.167 & 0.078 & -0.011 & 0.035 & -0.035 & 0.986 & 0.176 & 0.474 & 0.509 \\
\hline & Insolvent firms & 0.394 & 0.693 & 1.000 & 0.183 & 0.166 & 0.121 & 0.150 & 0.083 & 0.166 & -0.166 & 0.962 & 0.099 & 0.655 & 0.659 \\
\hline & All firms & 0.085 & 0.244 & 0.093 & 1.000 & 0.010 & 0.035 & 0.017 & 0.014 & 0.925 & -0.925 & 0.046 & 0.030 & 0.070 & 0.063 \\
\hline \multirow[t]{3}{*}{ RE/TA } & Solvent firms & 0.164 & 0.280 & 0.104 & 1.000 & 0.012 & 0.074 & 0.039 & 0.026 & 0.621 & -0.621 & 0.089 & 0.076 & 0.134 & 0.119 \\
\hline & Insolvent firms & 0.024 & 0.224 & 0.183 & 1.000 & 0.003 & -0.007 & 0.012 & 0.105 & 0.988 & -0.988 & -0.025 & -0.002 & 0.062 & 0.041 \\
\hline & All firms & 0.058 & 0.089 & 0.026 & 0.010 & 1.000 & 0.419 & 0.006 & 0.001 & 0.003 & $3-0.003$ & 0.028 & 0.332 & 0.024 & 0.022 \\
\hline \multirow[t]{3}{*}{$\mathrm{NI} / \mathrm{S}$} & Solvent firms & 0.024 & 0.042 & 0.016 & 0.012 & 1.000 & 0.461 & 0.004 & 0.001 & 0.005 & -0.005 & 0.021 & 0.462 & 0.017 & 0.014 \\
\hline & Insolvent firms & 0.467 & 0.432 & 0.166 & 0.003 & 1.000 & 0.424 & 0.201 & -0.020 & -0.020 & 0.020 & 0.120 & 0.900 & 0.215 & 0.225 \\
\hline & All firms & 0.195 & 0.293 & 0.158 & 0.035 & 0.419 & 1.000 & 0.044 & -0.042 & -0.023 & 0.023 & 0.173 & 0.445 & 0.177 & 0.175 \\
\hline \multirow[t]{3}{*}{ EBITDA/S } & Solvent firms & 0.153 & 0.287 & 0.167 & 0.074 & 0.461 & 1.000 & 0.046 & -0.053 & -0.049 & 0.049 & 0.181 & 0.992 & 0.185 & 0.184 \\
\hline & Insolvent firms & 0.333 & 0.269 & 0.121 & -0.007 & 0.424 & 1.000 & 0.176 & -0.035 & -0.037 & 0.037 & 0.157 & 0.248 & 0.278 & 0.252 \\
\hline & All firms & 0.038 & 0.131 & 0.078 & 0.017 & 0.006 & 0.044 & 1.000 & -0.003 & -0.006 & 0.006 & 0.071 & 0.018 & 0.030 & 0.036 \\
\hline \multirow[t]{3}{*}{$\mathrm{EBT} / \mathrm{TE}$} & Solvent firms & 0.030 & 0.153 & 0.078 & 0.039 & 0.004 & 0.046 & 1.000 & -0.003 & -0.012 & 0.012 & 0.071 & 0.047 & 0.028 & 0.034 \\
\hline & Insolvent firms & 0.494 & 0.431 & 0.150 & 0.012 & 0.201 & 0.176 & 1.000 & -0.092 & -0.028 & 0.028 & 0.146 & -0.009 & 0.297 & 0.311 \\
\hline & All firms & 0.257 & 0.000 & -0.009 & 0.014 & 0.001 & -0.042 & -0.003 & 1.000 & 0.066 & -0.066 & -0.019 & -0.017 & 0.088 & 0.084 \\
\hline \multirow[t]{3}{*}{ TE/TD } & Solvent firms & 0.277 & -0.006 & -0.011 & 0.026 & 0.001 & -0.053 & -0.003 & 1.000 & 0.143 & -0.143 & -0.021 & -0.052 & 0.088 & 0.084 \\
\hline & Insolvent firms & -0.211 & 0.028 & 0.083 & 0.105 & -0.020 & -0.035 & -0.092 & 1.000 & 0.181 & -0.181 & 0.042 & 0.035 & -0.164 & -0.205 \\
\hline & All firms & 0.102 & 0.198 & 0.063 & 0.925 & 0.003 & -0.023 & -0.006 & 0.066 & 1.000 & -1.000 & 0.011 & 0.006 & 0.092 & 0.068 \\
\hline \multirow[t]{3}{*}{ TE/TA } & Solvent firms & 0.239 & 0.194 & 0.035 & 0.621 & 0.005 & -0.049 & -0.012 & 0.143 & 1.000 & -1.000 & 0.008 & -0.050 & 0.190 & 0.143 \\
\hline & Insolvent firms & -0.034 & 0.183 & 0.166 & 0.988 & -0.020 & -0.037 & -0.028 & 0.181 & 1.000 & -1.000 & -0.046 & -0.007 & -0.005 & -0.031 \\
\hline & All firms & -0.102 & -0.198 & -0.063 & -0.925 & -0.003 & 0.023 & 0.006 & -0.066 & -1.000 & 1.000 & -0.011 & -0.006 & -0.092 & -0.069 \\
\hline \multirow[t]{3}{*}{ TD/TA } & Solvent firms & -0.239 & -0.194 & -0.035 & -0.621 & -0.005 & 0.049 & 0.012 & -0.143 & -1.000 & 1.000 & -0.008 & 0.050 & -0.190 & -0.143 \\
\hline & Insolvent firms & 0.034 & -0.183 & -0.166 & -0.988 & 0.020 & 0.037 & 0.028 & -0.181 & -1.000 & 1.000 & 0.046 & 0.007 & 0.005 & 0.031 \\
\hline & All firms & 0.181 & 0.418 & 0.985 & 0.046 & 0.028 & 0.173 & 0.071 & -0.019 & 0.011 & -0.011 & 1.000 & 0.087 & 0.488 & 0.507 \\
\hline \multirow[t]{3}{*}{ EBITDA/TA } & Solvent firms & 0.151 & 0.418 & 0.986 & 0.089 & 0.021 & 0.181 & 0.071 & -0.021 & 0.008 & -0.008 & 1.000 & 0.183 & 0.481 & 0.500 \\
\hline & Insolvent firms & 0.417 & 0.663 & 0.962 & -0.025 & 0.120 & 0.157 & 0.146 & 0.042 & -0.046 & 0.046 & 1.000 & 0.031 & 0.664 & 0.644 \\
\hline & All firms & 0.095 & 0.170 & 0.099 & 0.030 & 0.332 & 0.445 & 0.018 & -0.017 & 0.006 & -0.006 & 0.087 & 1.000 & 0.087 & 0.093 \\
\hline \multirow[t]{3}{*}{ EBIT/S } & Solvent firms & 0.153 & 0.301 & 0.176 & 0.076 & 0.462 & 0.992 & 0.047 & -0.052 & -0.050 & 0.050 & 0.183 & 1.000 & 0.185 & 0.191 \\
\hline & Insolvent firms & 0.079 & 0.096 & 0.099 & -0.002 & 0.900 & 0.248 & -0.009 & 0.035 & -0.007 & 0.007 & 0.031 & 1.000 & 0.071 & 0.094 \\
\hline & All firms & 0.769 & 0.272 & 0.482 & 0.070 & 0.024 & 0.177 & 0.030 & 0.088 & 0.092 & -0.092 & 0.488 & 0.087 & 1.000 & 0.980 \\
\hline \multirow[t]{3}{*}{ EBITDA/TD } & Solvent firms & 0.798 & 0.277 & 0.474 & 0.134 & 0.017 & 0.185 & 0.028 & 0.088 & 0.190 & -0.190 & 0.481 & 0.185 & 1.000 & 0.980 \\
\hline & Insolvent firms & 0.647 & 0.599 & 0.655 & 0.062 & 0.215 & 0.278 & 0.297 & -0.164 & -0.005 & 0.005 & 0.664 & 0.071 & 1.000 & 0.978 \\
\hline & All firms & 0.739 & 0.284 & 0.516 & 0.063 & 0.022 & 0.175 & 0.036 & 0.084 & 0.068 & -0.069 & 0.507 & 0.093 & 0.980 & 1.000 \\
\hline \multirow[t]{2}{*}{ EBIT/TD } & Solvent firms & 0.764 & 0.291 & 0.509 & 0.119 & 0.014 & 0.184 & 0.034 & 0.084 & 0.143 & -0.143 & 0.500 & 0.191 & 0.980 & 1.000 \\
\hline & Insolvent firms & 0.626 & 0.583 & 0.659 & 0.041 & 0.225 & 0.252 & 0.311 & -0.205 & -0.031 & 0.031 & 0.644 & 0.094 & 0.978 & 1.000 \\
\hline
\end{tabular}

Note. Values in bold indicate statistically significant correlations at the $5 \%$ level. 
Table A5

Correlations Two Years Prior to Insolvency

\begin{tabular}{|c|c|c|c|c|c|c|c|c|c|c|c|c|c|c|c|}
\hline Ratio & Group & CF/TD & NI/TA & EBIT/TA & $\mathrm{RE} / \mathrm{TA}$ & $\mathrm{NI} / \mathrm{S}$ & EBITDA/S & $\mathrm{EBT} / \mathrm{TE}$ & $\mathrm{TE} / \mathrm{TD}$ & TE/TA & $\mathrm{TD} / \mathrm{TA}$ & EBITDA/TA & EBIT/S & EBITDA/TD & EBIT/TD \\
\hline & All firms & 1.000 & 0.196 & 0.105 & 0.110 & 0.088 & 0.046 & 0.025 & 0.876 & 0.110 & -0.110 & 0.099 & 0.044 & 0.938 & 0.935 \\
\hline \multirow[t]{3}{*}{ CF/TD } & Solvent firms & 1.000 & 0.142 & 0.101 & 0.089 & 0.084 & 0.046 & 0.019 & 0.884 & 0.122 & -0.122 & 0.093 & 0.044 & 0.946 & 0.943 \\
\hline & Insolvent firms & 1.000 & 0.991 & 0.136 & 0.440 & 0.977 & 0.145 & 0.722 & 0.044 & -0.003 & 0.003 & 0.201 & 0.121 & 0.232 & 0.179 \\
\hline & All firms & 0.196 & 1.000 & 0.671 & 0.406 & 0.081 & 0.048 & 0.208 & -0.003 & 0.254 & -0.255 & 0.634 & 0.052 & 0.037 & 0.036 \\
\hline \multirow[t]{3}{*}{ NI/TA } & Solvent firms & 0.142 & 1.000 & 0.836 & 0.373 & 0.076 & 0.057 & 0.233 & -0.006 & 0.342 & -0.344 & 0.784 & 0.063 & 0.042 & 0.042 \\
\hline & Insolvent firms & 0.991 & 1.000 & 0.113 & 0.451 & 0.985 & 0.133 & 0.724 & 0.038 & 0.012 & -0.012 & 0.158 & 0.127 & 0.168 & 0.130 \\
\hline & All firms & 0.105 & 0.671 & 1.000 & 0.271 & 0.008 & 0.180 & 0.224 & -0.007 & 0.236 & -0.237 & 0.970 & 0.187 & 0.073 & 0.072 \\
\hline \multirow[t]{3}{*}{ EBIT/TA } & Solvent firms & 0.101 & 0.836 & 1.000 & 0.299 & 0.008 & 0.181 & 0.227 & -0.008 & 0.254 & -0.255 & 0.971 & 0.187 & 0.071 & 0.070 \\
\hline & Insolvent firms & 0.136 & 0.113 & 1.000 & 0.134 & 0.065 & 0.431 & -0.035 & 0.271 & 0.119 & -0.119 & 0.937 & 0.656 & 0.815 & 0.851 \\
\hline & All firms & 0.110 & 0.406 & 0.271 & 1.000 & 0.023 & 0.006 & 0.008 & 0.030 & 0.883 & -0.885 & 0.230 & 0.005 & 0.044 & 0.040 \\
\hline \multirow[t]{3}{*}{ RE/TA } & Solvent firms & 0.089 & 0.373 & 0.299 & 1.000 & 0.017 & 0.005 & -0.001 & 0.033 & 0.889 & -0.892 & 0.248 & 0.004 & 0.048 & 0.045 \\
\hline & Insolvent firms & 0.440 & 0.451 & 0.134 & 1.000 & 0.427 & 0.114 & 0.281 & 0.294 & 0.866 & -0.866 & 0.155 & 0.086 & 0.146 & 0.101 \\
\hline & All firms & 0.088 & 0.081 & 0.008 & 0.023 & 1.000 & 0.429 & 0.005 & -0.014 & -0.004 & 0.004 & 0.008 & 0.424 & 0.003 & 0.002 \\
\hline \multirow[t]{3}{*}{$\mathrm{NI} / \mathrm{S}$} & Solvent firms & 0.084 & 0.076 & 0.008 & 0.017 & 1.000 & 0.429 & 0.004 & -0.014 & -0.005 & 0.005 & 0.007 & 0.424 & 0.002 & 0.002 \\
\hline & Insolvent firms & 0.977 & 0.985 & 0.065 & 0.427 & 1.000 & 0.115 & 0.711 & -0.035 & -0.026 & 0.026 & 0.100 & 0.125 & 0.089 & 0.063 \\
\hline & All firms & 0.046 & 0.048 & 0.180 & 0.006 & 0.429 & 1.000 & 0.014 & -0.011 & -0.027 & 0.027 & 0.189 & 0.998 & 0.098 & 0.096 \\
\hline \multirow[t]{3}{*}{ EBITDA/S } & Solvent firms & 0.046 & 0.057 & 0.181 & 0.005 & 0.429 & 1.000 & 0.014 & -0.011 & -0.032 & 0.032 & 0.190 & 0.998 & 0.098 & 0.096 \\
\hline & Insolvent firms & 0.145 & 0.133 & 0.431 & 0.114 & 0.115 & 1.000 & 0.040 & 0.005 & 0.050 & -0.050 & 0.539 & 0.706 & 0.392 & 0.329 \\
\hline & All firms & 0.025 & 0.208 & 0.224 & 0.008 & 0.005 & 0.014 & 1.000 & -0.002 & -0.016 & 0.016 & 0.209 & 0.017 & 0.008 & 0.009 \\
\hline \multirow[t]{3}{*}{$\mathrm{EBT} / \mathrm{TE}$} & Solvent firms & 0.019 & 0.233 & 0.227 & -0.001 & 0.004 & 0.014 & 1.000 & -0.002 & -0.019 & 0.019 & 0.211 & 0.017 & 0.008 & 0.009 \\
\hline & Insolvent firms & 0.722 & 0.724 & -0.035 & 0.281 & 0.711 & 0.040 & 1.000 & -0.052 & -0.033 & 0.033 & 0.037 & -0.076 & 0.085 & 0.049 \\
\hline & All firms & 0.876 & -0.003 & -0.007 & 0.030 & -0.014 & -0.011 & -0.002 & 1.000 & 0.054 & -0.054 & -0.016 & -0.010 & 0.934 & 0.934 \\
\hline \multirow[t]{3}{*}{ TE/TD } & Solvent firms & 0.884 & -0.006 & -0.008 & 0.033 & -0.014 & -0.011 & -0.002 & 1.000 & 0.060 & -0.060 & -0.017 & -0.010 & 0.934 & 0.934 \\
\hline & Insolvent firms & 0.044 & 0.038 & 0.271 & 0.294 & -0.035 & 0.005 & -0.052 & 1.000 & 0.470 & -0.470 & 0.209 & 0.138 & 0.370 & 0.343 \\
\hline & All firms & 0.110 & 0.254 & 0.236 & 0.883 & -0.004 & -0.027 & -0.016 & 0.054 & 1.000 & -0.999 & 0.194 & -0.032 & 0.051 & 0.045 \\
\hline \multirow[t]{3}{*}{ TE/TA } & Solvent firms & 0.122 & 0.342 & 0.254 & 0.889 & -0.005 & -0.032 & -0.019 & 0.060 & 1.000 & -0.998 & 0.207 & -0.037 & 0.055 & 0.049 \\
\hline & Insolvent firms & -0.003 & 0.012 & 0.119 & 0.866 & -0.026 & 0.050 & -0.033 & 0.470 & 1.000 & -1.000 & 0.106 & 0.047 & 0.106 & 0.071 \\
\hline & All firms & -0.110 & -0.255 & -0.237 & -0.885 & 0.004 & 0.027 & 0.016 & -0.054 & -0.999 & 1.000 & -0.194 & 0.032 & -0.050 & -0.045 \\
\hline \multirow[t]{3}{*}{ TD/TA } & Solvent firms & -0.122 & -0.344 & -0.255 & -0.892 & 0.005 & 0.032 & 0.019 & -0.060 & -0.998 & 1.000 & -0.207 & 0.037 & -0.055 & -0.049 \\
\hline & Insolvent firms & 0.003 & -0.012 & -0.119 & -0.866 & 0.026 & -0.050 & 0.033 & -0.470 & -1.000 & 1.000 & -0.106 & -0.047 & -0.106 & -0.071 \\
\hline & All firms & 0.099 & 0.634 & 0.970 & 0.230 & 0.008 & 0.189 & 0.209 & -0.016 & 0.194 & -0.194 & 1.000 & 0.189 & 0.070 & 0.064 \\
\hline \multirow[t]{3}{*}{ EBITDA/TA } & Solvent firms & 0.093 & 0.784 & 0.971 & 0.248 & 0.007 & 0.190 & 0.211 & -0.017 & 0.207 & -0.207 & 1.000 & 0.190 & 0.068 & 0.063 \\
\hline & Insolvent firms & 0.201 & 0.158 & 0.937 & 0.155 & 0.100 & 0.539 & 0.037 & 0.209 & 0.106 & -0.106 & 1.000 & 0.609 & 0.858 & 0.815 \\
\hline & All firms & 0.044 & 0.052 & 0.187 & 0.005 & 0.424 & 0.998 & 0.017 & -0.010 & -0.032 & 0.032 & 0.189 & 1.000 & 0.098 & 0.098 \\
\hline \multirow[t]{3}{*}{ EBIT/S } & Solvent firms & 0.044 & 0.063 & 0.187 & 0.004 & 0.424 & 0.998 & 0.017 & -0.010 & -0.037 & 0.037 & 0.190 & 1.000 & 0.098 & 0.097 \\
\hline & Insolvent firms & 0.121 & 0.127 & 0.656 & 0.086 & 0.125 & 0.706 & -0.076 & 0.138 & 0.047 & -0.047 & 0.609 & 1.000 & 0.484 & 0.506 \\
\hline & All firms & 0.938 & 0.037 & 0.073 & 0.044 & 0.003 & 0.098 & 0.008 & 0.934 & 0.051 & -0.050 & 0.070 & 0.098 & 1.000 & 1.000 \\
\hline \multirow[t]{3}{*}{ EBITDA/TD } & Solvent firms & 0.946 & 0.042 & 0.071 & 0.048 & 0.002 & 0.098 & 0.008 & 0.934 & 0.055 & -0.055 & 0.068 & 0.098 & 1.000 & 1.000 \\
\hline & Insolvent firms & 0.232 & 0.168 & 0.815 & 0.146 & 0.089 & 0.392 & 0.085 & 0.370 & 0.106 & -0.106 & 0.858 & 0.484 & 1.000 & 0.967 \\
\hline & All firms & 0.935 & 0.036 & 0.072 & 0.040 & 0.002 & 0.096 & 0.009 & 0.934 & 0.045 & -0.045 & 0.064 & 0.098 & 1.000 & 1.000 \\
\hline \multirow[t]{2}{*}{ EBIT/TD } & Solvent firms & 0.943 & 0.042 & 0.070 & 0.045 & 0.002 & 0.096 & 0.009 & 0.934 & 0.049 & -0.049 & 0.063 & 0.097 & 1.000 & 1.000 \\
\hline & Insolvent firms & 0.179 & 0.130 & 0.851 & 0.101 & 0.063 & 0.329 & 0.049 & 0.343 & 0.071 & -0.071 & 0.815 & 0.506 & 0.967 & 1.000 \\
\hline
\end{tabular}

Note. Values in bold indicate statistically significant correlations at the $5 \%$ level. 
Table A6

Correlations Between One and Two Years Prior to Insolvency

\begin{tabular}{|c|c|c|c|c|c|c|c|c|c|c|c|c|c|c|c|}
\hline Ratio 2010 & Ratio 2011 & CF/TD & NI/TA & EBIT/TA & $\mathrm{RE} / \mathrm{TA}$ & $\mathrm{NI} / \mathrm{S}$ & EBITDA/S & EBT/TE & TE/TD & TE/TA & $\mathrm{TD} / \mathrm{TA}$ & EBITDA/TA & EBIT/S & EBITDA/TD & EBIT/TD \\
\hline & All firms & -0.019 & -0.021 & -0.013 & -0.001 & 0.004 & -0.004 & 0.016 & -0.008 & -0.001 & 0.001 & -0.015 & 0.004 & -0.018 & -0.017 \\
\hline \multirow[t]{3}{*}{ CF/TD } & Solvent firms & -0.027 & -0.044 & -0.019 & -0.019 & 0.003 & -0.010 & 0.016 & -0.009 & -0.017 & 0.017 & -0.021 & -0.008 & -0.023 & -0.021 \\
\hline & Insolvent firms & 0.015 & 0.011 & 0.008 & -0.006 & 0.011 & 0.004 & 0.010 & 0.029 & -0.002 & 0.002 & -0.001 & 0.010 & 0.018 & 0.016 \\
\hline & All firms & -0.017 & 0.034 & 0.020 & 0.014 & 0.007 & 0.004 & -0.001 & -0.028 & 0.021 & -0.021 & 0.019 & 0.020 & -0.027 & -0.029 \\
\hline \multirow[t]{3}{*}{ NI/TA } & Solvent firms & -0.053 & -0.011 & 0.002 & -0.019 & 0.002 & -0.012 & -0.003 & -0.039 & 0.006 & -0.005 & 0.004 & -0.010 & -0.051 & -0.053 \\
\hline & Insolvent firms & 0.018 & 0.014 & 0.004 & -0.007 & 0.009 & -0.006 & 0.023 & 0.019 & -0.005 & 0.005 & -0.006 & 0.005 & 0.010 & 0.013 \\
\hline & All firms & -0.015 & 0.052 & 0.035 & 0.022 & 0.012 & 0.006 & -0.004 & -0.030 & 0.038 & -0.038 & 0.031 & 0.026 & -0.026 & -0.026 \\
\hline \multirow[t]{3}{*}{ EBIT/TA } & Solvent firms & -0.041 & 0.016 & 0.019 & 0.021 & 0.005 & -0.009 & -0.005 & -0.032 & 0.049 & -0.048 & 0.016 & -0.007 & -0.038 & -0.039 \\
\hline & Insolvent firms & 0.218 & 0.219 & 0.214 & 0.007 & 0.168 & 0.067 & 0.045 & -0.006 & 0.041 & -0.041 & 0.199 & 0.123 & 0.244 & 0.236 \\
\hline & All firms & -0.009 & -0.001 & 0.010 & -0.027 & 0.003 & 0.002 & 0.024 & 0.007 & -0.022 & 0.022 & 0.009 & 0.006 & -0.019 & -0.013 \\
\hline \multirow[t]{3}{*}{ RE/TA } & Solvent firms & -0.026 & -0.028 & 0.001 & -0.065 & 0.001 & -0.017 & 0.026 & 0.005 & -0.052 & 0.052 & 0.002 & -0.015 & -0.031 & -0.024 \\
\hline & Insolvent firms & -0.015 & -0.035 & -0.043 & -0.053 & -0.010 & 0.010 & 0.029 & 0.018 & -0.045 & 0.045 & -0.059 & -0.010 & -0.036 & -0.022 \\
\hline & All firms & -0.114 & -0.100 & -0.065 & 0.023 & 0.000 & -0.006 & -0.007 & -0.002 & -0.011 & 0.011 & -0.069 & -0.002 & -0.111 & -0.100 \\
\hline \multirow[t]{3}{*}{$\mathrm{NI} / \mathrm{S}$} & Solvent firms & -0.124 & -0.135 & -0.068 & 0.058 & 0.000 & -0.007 & -0.007 & -0.002 & -0.027 & 0.027 & -0.071 & -0.007 & -0.113 & -0.102 \\
\hline & Insolvent firms & -0.002 & -0.010 & -0.020 & -0.006 & -0.011 & -0.012 & 0.017 & 0.019 & -0.004 & 0.004 & -0.029 & -0.011 & -0.011 & -0.009 \\
\hline & All firms & -0.098 & -0.027 & -0.015 & 0.069 & 0.002 & -0.001 & 0.004 & -0.002 & 0.050 & -0.049 & -0.035 & 0.002 & -0.097 & -0.082 \\
\hline \multirow[t]{3}{*}{ EBITDA/S } & Solvent firms & -0.108 & -0.040 & -0.017 & 0.179 & 0.001 & -0.003 & 0.003 & -0.002 & 0.114 & -0.114 & -0.037 & -0.003 & -0.099 & -0.084 \\
\hline & Insolvent firms & 0.137 & 0.139 & 0.155 & 0.005 & 0.116 & 0.088 & 0.022 & -0.063 & 0.001 & -0.001 & 0.145 & 0.087 & 0.138 & 0.135 \\
\hline & All firms & 0.027 & -0.010 & -0.016 & -0.010 & 0.002 & 0.004 & 0.001 & 0.008 & -0.033 & 0.033 & -0.015 & 0.005 & 0.028 & 0.030 \\
\hline \multirow[t]{3}{*}{$\mathrm{EBT} / \mathrm{TE}$} & Solvent firms & 0.028 & -0.021 & -0.019 & -0.037 & 0.002 & 0.002 & 0.001 & 0.007 & -0.087 & 0.087 & -0.018 & 0.003 & 0.027 & 0.029 \\
\hline & Insolvent firms & -0.045 & 0.060 & 0.069 & 0.033 & 0.013 & 0.006 & 0.024 & 0.356 & 0.041 & -0.041 & 0.037 & 0.026 & 0.037 & 0.032 \\
\hline & All firms & -0.001 & -0.002 & -0.004 & -0.002 & 0.001 & 0.000 & 0.001 & -0.003 & -0.006 & 0.006 & 0.000 & 0.000 & -0.002 & -0.002 \\
\hline \multirow[t]{3}{*}{ TE/TD } & Solvent firms & -0.002 & -0.006 & -0.005 & -0.010 & 0.001 & -0.001 & 0.001 & -0.003 & -0.017 & 0.017 & -0.001 & -0.004 & -0.003 & -0.003 \\
\hline & Insolvent firms & 0.012 & -0.031 & -0.098 & -0.078 & -0.009 & -0.089 & 0.178 & -0.068 & -0.048 & 0.048 & -0.111 & -0.019 & -0.075 & -0.059 \\
\hline & All firms & -0.008 & -0.010 & 0.001 & -0.027 & -0.008 & -0.018 & 0.022 & 0.007 & -0.026 & 0.027 & 0.001 & -0.005 & -0.021 & -0.013 \\
\hline \multirow[t]{3}{*}{ TE/TA } & Solvent firms & -0.017 & -0.026 & -0.003 & -0.064 & -0.008 & -0.017 & 0.023 & 0.007 & -0.066 & 0.066 & 0.000 & -0.012 & -0.027 & -0.019 \\
\hline & Insolvent firms & -0.034 & -0.052 & -0.073 & -0.047 & -0.038 & -0.053 & 0.047 & 0.012 & -0.035 & 0.035 & -0.091 & -0.033 & -0.074 & -0.057 \\
\hline & All firms & 0.008 & 0.010 & -0.001 & 0.027 & 0.008 & 0.018 & -0.022 & -0.008 & 0.026 & -0.027 & -0.001 & 0.006 & 0.021 & 0.013 \\
\hline \multirow[t]{3}{*}{ TD/TA } & Solvent firms & 0.017 & 0.026 & 0.003 & 0.064 & 0.008 & 0.017 & -0.023 & -0.007 & 0.066 & -0.066 & 0.001 & 0.012 & 0.027 & 0.019 \\
\hline & Insolvent firms & 0.034 & 0.052 & 0.073 & 0.047 & 0.038 & 0.053 & -0.047 & -0.012 & 0.035 & -0.035 & 0.091 & 0.033 & 0.074 & 0.057 \\
\hline & All firms & -0.004 & 0.052 & 0.041 & 0.026 & 0.018 & 0.015 & -0.007 & -0.026 & 0.039 & -0.039 & 0.036 & 0.031 & -0.010 & -0.010 \\
\hline \multirow[t]{3}{*}{ EBITDA/TA } & Solvent firms & -0.027 & 0.018 & 0.024 & 0.033 & 0.010 & -0.002 & -0.008 & -0.028 & 0.054 & -0.053 & 0.021 & 0.000 & -0.022 & -0.022 \\
\hline & Insolvent firms & 0.203 & 0.214 & 0.239 & 0.006 & 0.178 & 0.100 & 0.022 & 0.024 & 0.034 & -0.034 & 0.227 & 0.146 & 0.260 & 0.242 \\
\hline & All firms & -0.099 & -0.028 & -0.017 & 0.069 & 0.000 & -0.002 & 0.003 & -0.002 & 0.049 & -0.049 & -0.036 & 0.000 & -0.099 & -0.084 \\
\hline \multirow[t]{3}{*}{ EBIT/S } & Solvent firms & -0.109 & -0.042 & -0.019 & 0.177 & 0.000 & -0.004 & 0.003 & -0.002 & 0.111 & -0.111 & -0.038 & -0.004 & -0.101 & -0.086 \\
\hline & Insolvent firms & 0.193 & 0.177 & 0.147 & 0.037 & 0.114 & 0.044 & 0.083 & -0.089 & 0.048 & -0.048 & 0.139 & 0.058 & 0.160 & 0.152 \\
\hline & All firms & -0.002 & 0.007 & 0.004 & 0.007 & 0.002 & 0.000 & 0.009 & -0.003 & 0.006 & -0.006 & 0.002 & 0.003 & -0.003 & -0.002 \\
\hline \multirow[t]{3}{*}{ EBITDA/TD } & Solvent firms & -0.005 & 0.004 & 0.002 & 0.013 & 0.001 & -0.002 & 0.009 & -0.004 & 0.009 & -0.009 & 0.000 & -0.001 & -0.005 & -0.003 \\
\hline & Insolvent firms & 0.131 & 0.135 & 0.145 & -0.021 & 0.128 & 0.073 & -0.030 & 0.012 & 0.026 & -0.026 & 0.128 & 0.106 & 0.157 & 0.150 \\
\hline & All firms & -0.003 & 0.007 & 0.004 & 0.007 & 0.002 & 0.000 & 0.008 & -0.003 & 0.006 & -0.006 & 0.002 & 0.002 & -0.004 & -0.003 \\
\hline \multirow[t]{2}{*}{ EBIT/TD } & Solvent firms & -0.005 & 0.004 & 0.002 & 0.013 & 0.001 & -0.002 & 0.008 & -0.004 & 0.009 & -0.009 & 0.000 & -0.001 & -0.005 & -0.004 \\
\hline & Insolvent firms & 0.142 & 0.146 & 0.141 & -0.014 & 0.127 & 0.057 & -0.033 & -0.007 & 0.037 & -0.037 & 0.118 & 0.096 & 0.153 & 0.155 \\
\hline
\end{tabular}

Note. Values in bold indicate statistically significant correlations at the $5 \%$ level. 